\title{
EL JESUITA Y CONFESOR DE SANTA TERESA DE JESÚS RODRIGO ÁLVAREZ: CARACTERÍSTICAS Y GENEALOGÍA DE SU ESPIRITUALIDAD
}

\author{
POR \\ Antonio GonzÁlez Polvillo \\ Universidad de Sevilla
}

\section{RESUMEN}

Se estudia a uno de los personajes más influyentes de la espiritualidad sevillana de la primera mitad del siglo XVI: el jesuita confesor de Teresa de Ávila Rodrigo Álvarez. En este periodo se organiza un conventículo de espiritualidad evangélica, paulina, visionaria y profética que tiene su origen en el eje JerezLebrija y que pronto entroncará, a través de Rodrigo de Valer, con las ideas evangélicas y de vuelta a una Iglesia primitiva del canónigo magistral de la catedral de Sevilla Egidio, y a través de Rodrigo Álvarez con la Congregación de la Granada, una especie de escuela de espiritualidad hermética compuesta por artistas (Juan Bautista Vázquez, Vasco Pereira, Juan Martínez Montañés), clérigos seculares y monjas que tendrá su descendencia en personajes importantes en las peripecias de la definición del dogma de la Inmaculada Concepción como fueron Hernando de Mata y Bernardo de Toro.

Palabras ClaVE: Profecías, Inquisición, Reforma evangélica, Congregación de la Granada, Sevilla, Alumbrados, Bernardo de Toro, Hernando de Mata, Monjas, Compañía de Jesús.

\section{THE JESUIT AND CONFESSOR OF SANTA TERESA DE JESUS RODRIGO ALVAREZ: CHARACTERISTICS AND GENEALOGY OF ITS SPIRITUALITY}

\begin{abstract}
We will study to one of the most influential personages of the Sevillan spirituality of first half of century XVI: the Jesuit confessor of Teresa de Avila Rodrigo
\end{abstract}




\begin{abstract}
Alvarez. In this period a group of evangelical spirituality, paulina, visionary and prophetic organizes itself that has its origin in the axis Jerez-Lebrija and that soon will connect, through Rodrigo de Valer, with the evangelical ideas and from return to a primitive Church of the skillful canon of the cathedral of Seville Egidio, and through Rodrigo Alvarez with the Congregation of Granada, a species of school of hermetic spirituality composed by artists (Juan Bautista Vázquez, Vasco Pereira, Juan Martínez Montañés), clergymen and nuns whom its descendants in important personages in the eventful journeys of the definition of the dogma of the Immaculate Conception will have as they were Hernando de Mata and Bernardo de Toro.
\end{abstract}

KEY WORDS: Prophecies, Inquisición, Evangelical Reformation, Congregation of Granada, Seville, Alumbrados, Bernardo de Toro, Hernando de Mata, Nuns, Society Iesu.

Recibido/Received 2010-06-11

Aceptado/Accepted 2010-11-05

En 1980 Antonio Domínguez Ortiz publicaba un artículo en el que daba cuenta de una asociación religiosa establecida en Sevilla con un marcado carácter hermético, perseguida por la Inquisición debido a su alumbradismo y conocida con el nombre de Congregación de la Granada. ${ }^{1}$ El recordado historiador declaraba la precipitación y la falta de explotación del filón que proporcionaba la correspondencia del Tribunal de la Inquisición de Sevilla con la Suprema, custodiada en el Archivo Histórico Nacional, por parte de Bernardino Llorca en su trabajo sobre los alumbrados sevillanos. Reconocía que Álvaro Huerga sí que lo hizo en mayor medida, el cual se hallaba entonces trabajando sobre los alumbrados de Sevilla. ${ }^{2}$ A pesar de ello y «entre tanto», afirmaba: «me voy a permitir adelantar algunas noticias sobre un episodio del que hasta ahora no se tienen más que escasas y vagas referencias».

Siguiendo esta línea de intención e investigación pretendemos ahora, en lo que es un adelanto de una próxima monografía, profundizar en la espiritualidad del confesor de Teresa de Jesús, Rodrigo Álvarez, cabeza que fue de esa Congregación, y fundar una genealogía de su especial espiritualidad que, en cierta medida, será como establecer la de buena parte de la sensibilidad religiosa, más o menos alumbrada, de la Sevilla de los siglos XVI y XVII. ${ }^{3}$

\footnotetext{
${ }^{1}$ El artículo fue consecuencia del I Symposium Internacional sobre la Inquisición Española, celebrado en Cuenca en noviembre de 1978. Y el trabajo en cuestión, Domínguez Ortiz, A. 1980. «La Congregación de la Granada y la Inquisición de Sevilla. Un episodio de la lucha contra los 'alumbrados'». La Inquisición española. Nueva visión, nuevos horizontes: 637-646. Madrid. Fue editado más tarde en un pequeño volumen: Domínguez Ortiz, A. 1983. Sociedad y mentalidad en la Sevilla del Antiguo Régimen: Sevilla, 161-177. Sevilla.

${ }^{2}$ Llorca, B. 1980. La Inquisición española y los alumbrados: (1509-1667): según las actas originales de Madrid y de otros archivos. Salamanca. Huerga, A. 1988. Historia de los alumbrados (15701630). IV Los alumbrados de Sevilla (1605-1630). Madrid: FUE.

${ }^{3}$ Una sucinta genealogía, pero con el valor de estar escrita por un protagonista principal de ella,
} 


\section{Gómez Camacho, la influencia profética de San Francisco de Paula EN LOS INICIOS JEREZANOS Y SU CONEXIÓN LEBRIJANA}

Domínguez Ortiz establecía el origen de la Congregación de la Granada a través de dos documentos que luego emplearía Huerga, para venir a decir esencialmente lo mismo, partiendo de lo declarado por otro de sus cabezas, el clérigo sevillano Bernardo de Toro. Aseguraba éste que fue fundada por Gómez Camacho un seglar, cerrajero de profesión, natural de Cumbres Altas aunque afincado en Jerez de la Frontera ciudad en la que viviría desde 1541 hasta su muerte acaecida en 1553. Lo hizo después de su casamiento con Catalina Jiménez con la que tendría descendencia. Ella también llegó a ser visionaria. ${ }^{4}$ En Jerez Gómez Camacho estableció contacto con Marta de San Andrés, discípula espiritual de San Francisco de Paula y monja del convento de Mínimas, de quien aprendería «la virtud». ${ }^{5}$ Si bien parece que Gómez Camacho debió aprender algo más de Marta de San Andrés, pues ésta era también visionaria como lo atestigua una crónica manuscrita conservada en el citado convento jerezano:

Se apareció Nuestra Señora del coro alto a la Hermana Sor Marta de San Andrés, siendo Prelada la Reverenda Madre Sor Beatriz de Ávila. Se halló en la puerta Reglar, entre dos paredes, sentada en un cojín o almohada, año de 1540.

Sor Marta de San Andrés, una noche, al encender la luz que estaba en el arco de la puerta, oyó clara y distintamente estas palabras: Di a tu Prelada que me saque de este sitio, que vengo a ser Correctora de esta Comunidad.

La Prelada, Sor Beatriz Dávila, religiosa de gran santidad y dotes de gobierno, prestó atención a las palabras que le comunicó la Hermana y no hizo más. A la noche siguiente y a la misma hora la hermana Sor Marta oyó las mismas textuales palabras, que comunicó de nuevo a la Prelada. Llegada la noche tercera la Rvda. Madre siguió los pasos de la leguita sin que esta lo advirtiera. Al encender la lámpara oyó la misma voz de las dos noches anteriores que le decía: Di a tu Prelada, que oyéndome está, que me saque de este

puede verse en Jesús María, P. de. 1663. Vida, virtudes y dones soberanos del venerable y apostolico padre Hernando de Mata, con elogios de svs principales dicipvlos. Por Fr. Pedro de Iesv María, Monge de la Congregación Reformada, del Orden de san Basilio Magno, del Yermo del Tardon. Dedicalo al Mysterio de la Inmaculada Concepción de María Santíssima Señora Nuestra. 3v-5v. Málaga: Mateo López Hidalgo. Se trata del Memorial que Bernardo de Toro elevó al Inquisidor General Don Bernardo de Sandoval y Rojas, fechado el 21 de noviembre de 1615. El propio Pedro de Jesús María fija la clave genealógica de esta espiritualidad y lo presenta como el memorial «donde se trata la espiritual genealogía, que trae su origen y principio desde S. Francisco de Paula, hasta el Padre Bernardo de Toro, Autor del mismo memorial». Ibídem, p. 3v. Es precisamente esta genealogía, desde Francisco de Paula hasta Bernardo de Toro pasando por Hernando de Mata y Rodrigo Álvarez, la que nosotros pretendemos poner en valor en este trabajo.

${ }^{4}$ A.H.N. Inquisición, Leg. 2957/2. Memorial de Bernardo de Toro.

${ }^{5}$ Domínguez Ortiz, A. 1983: 165. Según F. Campese el convento de Mínimas de Jerez fue fundado en torno a 1514, vid. Campese Gallego, F. 2008. «Gómez Camacho: Un profeta paradójico en el Siglo de Oro», Investigaciones históricas, 28: 13 n. 5. En la página web del convento, www.minimas.org, así como en las crónicas de la orden, como veremos más abajo, se asegura que las mínimas jerezanas llegaron al convento, procedentes de Andújar, en 1524. 
sitio que vengo a ser Correctora de esta Comunidad. Entonces Sor Marta advirtió que la Prelada estaba a su lado.

Como en aquel lugar no había alteración ninguna, no sabían cuál era el sitio señalado por la misteriosa voz. Avisado un maestro de obras estudió detenidamente los dos pilares del arco y advirtió que no estaba hueco. Después de un trabajo delicado pero relativamente corto, se descubrió una concavidad y depositada en ella una bellísima imagen de la Stma. Virgen, sentada sobre un cojín». ${ }^{6}$

No cabe duda de que la especial espiritualidad profética, milenarista y visionaria del calabrés San Francisco de Paula (1416-1507), que ahora transmite a Camacho Marta de San Andrés, está detrás de todo el misterio del profetismo, el milenarismo, el reformismo y, en consecuencia, el inmaculismo de la futura religiosidad sevillana y, especialmente, de la Congregación de la Granada, de ahí la necesidad que nos impusimos de establecer tanto su génesis como su desarrollo genealógico. ${ }^{7}$ No puede ser este el lugar para extendernos sobre San Francisco de Paula, pero sí es necesario establecer el entronque de las premisas fundamentales que caracterizan la espiritualidad del fundador mínimo con la de Gómez Camacho y, por consiguiente, con la de buena parte de la especial espiritualidad sevillana.

Entre un buen número de cartas de Paula que manejó el cronista de la orden, fray Lucas de Montoya, eligió doce para su publicación. ${ }^{8}$ Se trata de las enviadas al aragonés, estante en Nápoles, Simón de la Limena. En algunas de ellas el mínimo da cuenta de una singular profecía que, en la línea de las que expresó en su Expositio in Apocalypsin Joaquín de Fiore (1145-1202), y tantos otros de sus seguidores, con su profecía de la Parusía o segunda venida de Cristo, fijada

${ }^{6}$ La crónica de esta visión está inserta en la página web, ya citada, del Monasterio de Mínimas de la Purísima Concepción de Jerez de la Frontera. Establecimos comunicación con el convento interesándonos por Marta de San Andrés y las fuentes que aluden a ella, pero nos dijeron que sobre esta interesante monja solo existía la información que aquí aportamos. La imagen de la Virgen emparedada aún se encuentra en el coro alto del citado convento. Agradecemos la amabilidad mostrada por la Madre Superiora Sor Josefina García.

${ }^{7}$ Detrás de todo el movimiento del inmaculismo sevillano estuvo la Congregación de la Granada que buscó insistentemente la definición, por parte de Roma, del dogma con el cual daría comienzo la Reforma de la Iglesia que sus miembros protagonizarían. Vid. además de infra, González Polvillo, A. 2009/2010. «La Congregación de la Granada, el inmaculismo sevillano y los retratos realizados por Francisco Pacheco de tres de sus principales protagonistas: Miguel Cid, Bernardo de Toro y Mateo Vázquez de Leca». Atrio. Revista de Historia del Arte. 15-16: 47-72, especialmente 50 y 54-55. González Polvillo, A. 2011. «Inquisidores, dominicos y alumbrados de la Congregación de la Granada en la génesis del inmaculismo sevillano del siglo XVII». Anuario de Historia de la Iglesia Andaluza: 117-142.

${ }^{8}$ Montoya, L. de. 1619. Crónica General de la Orden de los Mínimos de San Francisco de Paula su fundador: donde se trata de su vida y milagros, origen de la Religión, erection de Prouincias y varones insignes Della: 395-406. Madrid: Bernardino de Guzmán. No entramos aquí en la posibilidad de la falsedad de estas cartas, no interesa puesto que, sean o no auténticas, circularon durante los siglos XVI y XVII como auténticas y, por supuesto, cumplieron su misión de difusión. Sobre la utilización de las profecías de Paula en otro contexto Vid. Christian, W. A. 1996. Visionaries. The Spanish Republic and the Reing of Christ: 688 y ss. Berkeley-Los Angeles-London.

Hispania Sacra, LXIV

129, enero-junio 2012, 141-186, ISSN: 0018-215-X, doi: 10.3989/hs.2012.005 
para 1260, con la idea de una reforma de la Iglesia en la dirección de lo preconizado por Cristo en el Evangelio, está en la base de las creencias proféticas y de reformatio ecclesiae de Camacho, de nuestro biografiado, del tándem Rodrigo de Valer-Juan Gil «Egidio»y, desde luego, de la sevillana Congregación de la Granada. ${ }^{9}$ En la primera carta, fechada en Paula el 25 de marzo de 1455, ante el deseo de Limena de tener descendencia, el fundador mínimo le profetiza que en efecto la tendría, pero además:

vuestra Santa generación será marauillosa sobre la tierra, entre la qual tendrá vno de vuestros descendientes que será como el Sol entre las estrellas. El tal hombre será en su puericia y adolescencia casi santo, mas en su juuentud será gran pecador, después se conuertirá todo a Dios y hará gran penitencia, y seranle perdonados todos los pecados, y tornará a ser Santo. Será gran Capitán y Príncipe de gente Santa, llamada los Santos Crucifijos de IeSu Christo, con los quales deshará la Seta de Mahoma con todo el resto de los infieles, aniquilará todas las heregías y tiranías del mundo: reformará la Iglesia de Dios con sus sequaces, los quales serán los mejores hombres del mundo, en Santidad, en armas, en letras, y en toda otra virtud, que tal es la voluntad del altissimo; tendrá el dominio de todo el mundo, temporal y espiritual, y regirán la Iglesia de Dios: In Sempiterna saecula saeculorum amen. ${ }^{10}$

Paula predice que un descendiente de un español, Simón de la Limena, aparte de aniquilar las herejías del mundo, reformará a la Iglesia como príncipe y con la ayuda de sus seguidores, los Santos Crucifijos. Unos seguidores que destacarán en armas, en letras y, en general, en todas las virtudes; a partir de esa reforma-lucha y por todos los siglos este príncipe elegido dominaría el mundo tanto en lo temporal como en lo espiritual. En una carta de abril del mismo año, Paula vuelve sobre la profecía, ahora anuncia que el descendiente de Limena, que al mando de esos Crucíferos luchará contra el mal, es descendiente a su vez de Santa Elena, la descubridora de la cruz, y de Constantino, el emperador de la cruz y, a través de él, de Pipino y, por él, del español Limena: «O Señor Simón tal hombre será de vuestros decendientes porque vos venís de Pipino». Por virtud de Dios, este príncipe aparte de aniquilar a los herejes, tiranos e infieles: «hará grandissimo exército, y los Ángeles combatirán con ellos, y matarán todos los rebeldes del altíssimo». ${ }^{11}$

Cinco años más tarde, en la carta sexta enviada a Simón de la Limena el 25 de marzo de 1460, doscientos años después de la fecha profetizada por Fiore

${ }^{9}$ La bibliografía sobre Joaquin de Fiore es inmensa e inabarcable, pero todavía sigue siendo útil, magnífica diría yo, la obra sobre el milenarismo y la dimensión de su personalidad que nos da Norman Cohn cuando dice que Fiore fue «el inventor del nuevo sistema profético, el cual iba a ser el que mayor influencia ejerciera en Europa hasta la aparición del marxismo». Vid. Cohn, N. 1989. En pos del Milenio. Revolucionarios milenaristas anarquistas místicos de la Edad Media: 107 y ss. Madrid: Alianza Editorial.

${ }^{10}$ Montoya, L. de. 1619: 395.

${ }^{11}$ Ibídem, p. 398. 
para la Parusía, Paula vuelve sobre su profecía, exhorta a los príncipes temporales y espirituales del mundo a que esperen «el grandíssimo açote que vendrá sobre ellos», al que seguirá «los fielíssimos escogidos del altíssimo, Santos Crucíferos», quienes a la vista de que no podrían vencer a los herejes con las letras, emprenderían su lucha con las armas, una lucha en la que habrían abundantes muertos tanto buenos como malos, en la que «los buenos serán martyres de IeSu Christo». Los Crucíferos, tras ir contra los infieles se volverían contra los malos cristianos «y matarán a todos los rebeldes de IeSu Christo [...] y regirán y gouernarán el mundo santamente [...] de vuestro linage será el fundador de tal gente santa». ${ }^{12}$ Paula se pregunta en la carta sobre cuándo tendría lugar tanto la lucha como la reforma y el comienzo de un nuevo reino. No lo sabía pero sí que estaba cerca y que se regiría bajo el Gobierno del Pastorado: «gaudeamus omnes, nosotros que estamos en seruicio del altissimo porque se allega ya cerca la gran visita, y reformación del mundo, será vn ganado y vn pastor».

En la carta novena, enviada a Limena y fechada el 7 de marzo de 1465, Paula vuelve a anunciar la inminencia de la Parusía: «Ya se va acercando la hora que la diuina Magestad, visitará el mundo con la nueua Religión de los Santos Crucíferos, con el Crucifixo leuantado sobre el más alto estandarte». Repite la lucha que tendrá lugar y los ríos de sangre que procurarán los miembros de la última religión de todos los tiempos. Paula afirma lo grato a Dios que serán: «O Santos Crucíferos escogidos del altíssimo, ¿quánto seréis gratíssimos al gran Dios? Mucho más por cierto que lo fue el pueblo de Israel»; y también vuelve a exponer el programa a desarrollar por la nueva religión:

Vosotros destruiréis la maldita Seta Mahometana, vosotros pondréis fin a toda suerte de infieles, Heregías, y setas del mundo, y seréis el acabamiento de todos los tiranos: vosotros pondréis silencio con perpetua paz, por todo el vniuerso mundo: vosotros haréis santos a todos los hombres, o por fuerça o por voluntad.

Paula ahora nos aporta un nuevo dato. Además de volver a insistir en la descendencia de Simón de la Limena, el fraile mínimo afirma que el creador de esa nueva religión de los Crucíferos será un hijo suyo:

Señor Simón mío hermano en Christo, y compañero caríssimo, alégrese vuestra alma, q. ${ }^{\text {e }}$ el gran Dios se digna por medio de vn decendiente vuestro, y hijo mío bendito, dar vna Religión tan Santa al mundo, la vltima de todas y la más amada de la Magestad diuina. Vencedor, vencedor, se llamará su fundador, vencerá el Mundo, la Carne, y el Demonio, Laus Deo. ${ }^{13}$

No cabe duda de que atendiendo al pensamiento religioso y profético de Camacho y de toda su genealógica estirpe espiritual, las ideas y profecías que más

\footnotetext{
${ }^{12}$ Ídem.

${ }^{13}$ Ibídem, p. 401.
}

Hispania Sacra, LXIV

129, enero-junio 2012, 141-186, ISSN: 0018-215-X, doi: 10.3989/hs.2012.005 
adelante veremos expresadas por miembros de la Congregación de la Granada, transmitidas por el propio Camacho, tienen claras connotaciones con la profecía de San Francisco de Paula sobre la última de las religiones y su papel reformador en el nuevo Reino del Milenio, una vez vencidas las fuerzas del Anticristo. Parece obvio que Camacho aprendió esas profecías de su maestra espiritual, la monja mínima Marta de San Andrés, quien la habría llevado por transmisión al convento de Jerez procedente del de Andújar. ${ }^{14}$ Gómez Camacho inicia así una nueva religión, la de los Crucíferos, que más tarde se concretará en la Congregación de la Granada, en la que con toda seguridad se sintió el elegido, el hijo espiritual de Francisco de Paula, tal como había profetizado el santo, dispuesto a formar el ejército que, con el signo de la cruz como estandarte y después de la Parusía, lucharía, él mismo o su descendencia espiritual, contra el Anticristo en una guerra en la que alcanzaría una gran victoria luego de la cual Cristo establecería su reinado en la tierra durante el Milenio.

Tras las virtuosas enseñanzas de Marta de San Andrés, Camacho se convirtió en un pseudo profeta, visionario y dominado por continuos arrobos. ${ }^{15}$ Fue además el maestro espiritual de un grupo o conventículo. El espíritu virtuoso recibido por la monja mínima fue así comunicado a sus seguidores, que denominaron a Camacho y a su mujer con los apelativos de padre y madre. En esta labor docente llegó a escribir un tratado titulado Libro de los Estados cuya edición y circulación prohibió la Inquisición. ${ }^{16}$

${ }^{14} \mathrm{El}$ convento de Andújar, primera comunidad de monjas mínimas, se fundó en 1495, con la donación de unas casas por parte del conde de Lucena y con la aprobación del propio San Francisco de Paula con el que mantuvo relación epistolar y quien, como narra la crónica, en el mismo año de su muerte, 1507, se apareció de forma milagrosa a una monja del convento a quien curó una mano. En 1524, salieron del convento de Andújar un grupo de monjas para fundar el convento de Jerez de la Frontera. La gran difusión que la profecía de San Francisco de Paula iba a tener la da a conocer él mismo en la carta decimoprimera, fechada el 13 de agosto de 1469, en la que, además de volver a repetirla, afirma la posesión de su espíritu profético y la difusión de esta gran profecía: «porq. a mí indigno, pobre pecador, se ha dignado darme espíritu profético con claríssimas profecías no oscuras como a otros sieruos las ha hecho escriuir y decir escuramente. Yo sé que de los incrédulos y gente precita no serán sino burladas mis letras y que no las creerán, mas en los fieles espíritus Católicos que aspiran al Santo Parayso, estas letras engendrarán tanta suauidad en el amor diuino que se deleytarán leyéndolas muchas vezes, y procurarán sacar copias dellas con grandíssimo feruor, que tal es la uoluntad del altíssimo. En estas letras se conocerá quién es de Christo bendito, y quién predestinado, o precito, y mucho más en la santa señal de Dios viuo, que quien la reurenciará, amará, y traerá, será santo de Dios». Montoya, L. de. 1619: 403-404.

${ }^{15}$ El célebre Inquisidor General y arzobispo de Sevilla, Fernando de Valdés, entre los años 1549 y 1551 en que estuvo en Sevilla, examinó espiritualmente a Gómez Camacho, al que no encontró ninguna proposición herética, es más, le regaló su propia cruz pectoral con la que Camacho, el jefe de los Crucíferos, realizó muchos milagros: «el dicho Inquisidor General le dio en vn bolso algunos doblones, con que se labró vna casa y vna Cruz de plata que el dicho Arçobispo e Inquisidor general traía al cuello, con la qual el dicho P. Camacho hazía después muchos milagros». Jesús María, P. de. 1663: 4.

${ }^{16}$ A.H.N. Inquisición, leg. 2957/2. Joan Tello, Sevilla 22 de febrero de 1616. Testimonio en Relaçión de lo que se a hallado en el sancto officio de la Inquiss. ${ }^{\text {on }}$ de Seu. ${ }^{a}$ contra Gomez Camacho vez. ${ }^{\circ}$ 
Camacho llevó a cabo su labor proselitista en un eje espiritual Jerez-Lebrija, en el que poco a poco fermentó una religiosidad especial, evangélica, visionaria y de elegidos que, tras plantarse en Jerez, terminó germinando en Lebrija formándose allí una auténtica y singular espiritualidad lebrijana que pronto se trasladó a Sevilla. Entre sus profecías cabe señalar por su importancia para entender la persecución posterior que sufrirá la Congregación de la Granada, a instancias con toda seguridad de los dominicos, la siguiente:

el dicho Padre Camacho, en vn ra[p]to de su oración, y hablando el mismo Dios por él dixo muchas cosas que están escritas, y aprouadas en el Santo Tribunal de la Inquisición: y entre ellas vna fue dezir, que la Virgen María Nuestra Señora, auía sido concebida sin pecado original, y que se escriviesse assí; porque los años adelante auía de ser necessario este testimonio en la Santa Iglesia. ${ }^{17}$

\section{Gómez Camacho, Rodrigo de Valer y los «Luteranos» De Sevilla}

Fruto de esta labor de enseñanza espiritual, surgieron en Lebrija otros visionarios y elegidos, discípulos de Gómez Camacho, como la monja Francisca de Vera, abadesa del convento de la Concepción, Rodrigo de Valer y Rodrigo Álvarez, nuestro biografiado. El primer contacto de esta espiritualidad con Sevilla fue a través de Rodrigo de Valer, relacionado con el canónigo magistral de la catedral sevillana Juan Gil Egidio, al que «convirtió», entroncando así una espiritualidad evangélica, visionaria, profética y milenarista con otra, si se quiere, más profunda e intelectualmente evangélica -evangélicas las dos aunque, tal vez, por distintos caminos- acusada por la Inquisición, y también por algunos historiadores, de luterana. ${ }^{18}$

de la çiudad de Xerez de la fronter. ${ }^{a}$ En el fol. $9 \mathrm{v}$ de este documento, uno de los cuatro calificadores del Santo Oficio que estudiaron el caso de Gómez Camacho, el franciscano Francisco del Castillo, recomendó el secuestro del tratado. Nosotros hemos tenido la suerte de hallarlo, inserto en un códice de una biblioteca particular sevillana y al que en adelante denominamos Códice de la Granada, por hallarse inserto en él un buen número de documentos relativos a importantes miembros de la misma.

${ }^{17}$ Noticia que nos transmite Bernardo de Toro y Mateo Vázquez de Leca en su célebre memorial de 1615. Vid. A.H.N. Inquisición, leg. 2957/2; Jesús María, P. de. 1663: 5r. Las vicisitudes de este santón pueden seguirse en Huerga, A. 1988: 35-42, que sigue el memorial de Bernardo de Toro y los restos del proceso inquisitorial. Para la verdadera significación del inmaculismo sevillano apoyado en esta profecía de Camacho vid. además de infra, González Polvillo, A. 2009/2010: 47-72.

${ }^{18}$ Ríos de tinta han corrido para analizar los hechos reformadores del grupo de luteranos de Sevilla, entre los que Rodrigo de Valer ha sido considerado por la historiografía internacional, en un tema de estudio tan querido para la misma, como una de sus figuras más sobresalientes. Algo que, como veremos aquí, es muy discutible pues la religiosidad de Valer no es luterana sino, como la de Camacho, claramente visionaria; aunque, todo hay que decirlo, su entronque con Egidio debió producir en Valer un «hibridismo espiritual» que se demuestra en el distanciamiento con Camacho. Lo más completo hasta ahora sobre la reforma sevillana es la obra de López Muñoz, T. 2011. La Reforma en la Sevilla del siglo XVI: 2 vols. Sevilla: MAD. Sobre la relación entre Camacho y Valer vid. además de infra, Boeglin, M.

Hispania Sacra, LXIV

129, enero-junio 2012, 141-186, ISSN: 0018-215-X, doi: 10.3989/hs.2012.005 
Rodrigo de Valer sirvió de maestro en una especie de nueva retórica de la predicación a Egidio y, a pesar de que el lebrijano era «de clase humilde, inculto y que no tenía fama de muy cuerdo»; a pesar, también, de que veinte y seis años antes había sido acusado en Sevilla «por seudoprofeta, seudoapóstol y vilísimo impostor», el canónigo aceptó sus indicaciones «aprendiendo de él el verdadero Evangelio de Cristo» y quedó transformado para siempre.

Fue así como la virtud de la espiritualidad lebrijana, de procedencia milenarista y profética paulino-jerezana, con las connotaciones de renovatio ecclesiae que ya conocemos, fue transmitida a Sevilla en un primer lugar a Egidio, Francisco de Vargas y luego a Constantino Ponce de la Fuente y otros: «el espíritu de Dios comunicó tal virtud a las palabras del consejero, que desde aquella hora Juan Gil, cambiado en otro hombre, juzgó inútiles y vanos todos los estudios y ejercicios de su vida pasada y se dio cuenta de que tenía que introducirse por otro camino en la sabiduría, de la que ni aun el alfabeto había aprendido». ${ }^{19}$

Ante la información respecto de Gómez Camacho que Mateo Vázquez de Leca y Bernardo de Toro enviaban el 21 de noviembre de 1615 al Inquisidor General don Bernardo de Sandoval y Rojas, en aras de lograr el dogma de la Inmaculada, la Suprema ordenó a los inquisidores de Sevilla comprobar los datos que sobre este habían aportado los dos pro-inmaculistas sevillanos, a lo que contestaron el 22 febrero de 1616 aludiendo que «por no se aver podido hallar el processo original de Gómez Camacho, se sacó el testim. ${ }^{\circ}{ }^{\text {q }}{ }^{\text {e }}$ será con esta del Proçesso de R. ${ }^{\circ}$ de Valer vz. ${ }^{\circ}$ de la Villa de Lebrixa q. ${ }^{\text {e }}$ estuuo preso en este S. ${ }^{\circ}$ off. ${ }^{\circ} \gg .{ }^{20} \mathrm{El}$ análisis del documento adjuntado por los inquisidores sevillanos, en el que se trata de espigar datos de Gómez Camacho insertos en el proceso de

2007. «Valer, Camacho y los «cautivos de la Inquisición». Sevilla 1540-1541». Cuadernos de Historia Moderna, 32: 113-134.

${ }^{19}$ Así lo narra Reginaldo Gonsalvius Montano en su Artes aliquot. Vid. la versión de Castrillo Benito, N. 1991. El «Reginaldo Montano»: primer libro polémico contra la Inquisición Española: 258-270 Madrid: CSIC. En efecto, Rodrigo de Valer fue acusado, en clara similitud con su «hermano» y amigo Camacho, de visionario y de proclamarse profeta enviado por Dios, el mismo Montano nos dice que en el Sagrario de la catedral de Sevilla aún se podía leer su sambenito que decía: «Rodrigo de Valer, natural de Nebrija, apóstata y seudoapóstol de Sevilla, que dijo ser enviado de Dios», p. 264. Sobre Rodrigo de Valer hay abundantes noticias en Menéndez Pelayo. M. 1987. Historia de los heterodoxos españoles. Madrid: T. II, 53-66. Madrid: BAC. También en Huerga, A. 1988: 42-44. Gil, J. 2005. «Nuevos documentos sobre Rodrigo de Valer», en P. M. Piñero (coord.) Dejar hablar a los textos: Homenaje a Francisco Márquez Villanueva: 739-774. Sevilla: Secretariado de Publicaciones de la Universidad de Sevilla. López Muñoz, T. 2011: vol. I 60-70; y, sobre todo, tanto en la citada Artes aliquot como en Valera, C. 1851. Tratado del papa y de la misa: 241-247 Madrid: Edición de Usoz del Río.

${ }^{20}$ A.H.N. Inquisición, leg. 2957/2. El documento relativo al proceso de Rodrigo de Valer que adjuntaban los inquisidores sevillanos por mano del notario del secreto Joan Tello, lleva por título: Testimonio en relaçión de lo que se a hallado en el sancto offiçio de la Inquiss..$^{\text {on }}$ de Seu. ${ }^{a}$ contra Gomez Camacho, $v z .^{o}$ de la çiudad de Xerez de la frontr. ${ }^{a}$, al que nosotros seguimos ahora. M. Boeglin. 2007: 115, afirma que el motivo de este memorial de los dos pro-inmaculistas sevillanos obedecía a un intento de iniciar los trámites de beatificación de Camacho, cosa inaudita. 
Rodrigo de Valer y en las que se analizaban las proposiciones tocantes a Camacho, no puede tener cabida aquí, de manera que lo posponemos para la anunciada monografía; de cualquier manera, el documento ya ha sido analizado por Huerga y Boeglin, aunque con diferentes miradas. Sí debemos incidir en que, si bien en un principio Camacho parece defender ante la Inquisición a Rodrigo de Valer, a quien considera su amigo y llama hermano, en los momentos previos al encarcelamiento de este, que tiene lugar el 3 de marzo de 1540, la relación entre los dos pseudo-profetas termina por romperse. Camacho cambia de actitud y enfundado en la coartada de una revelación, parece denunciar a Rodrigo de Valer a la propia Inquisición: «le fue dicho por los demonios hipócrita es Valer, quemen a Valer y que le dijeron que esto desea Lucifer». ${ }^{21}$

Este hecho nos lleva a intentar establecer la verdadera relación de Gómez Camacho con la Inquisición. Lo primero que parece advertirse es su estrecha correspondencia con la misma, aquí lo vemos actuar como un auténtico consejero inquisitorial que no duda en denunciar a su «hermano» y amigo Rodrigo de Valer, tal vez, eso aún no lo sabemos, porque lo encuentre demasiado «intelectualizado», es decir, demasiado inserto en el grupo reformista sevillano encabezado por Egidio y, por lo tanto, con errores teológicos que, aunque insistieran en la reformatio, lo desviaban de su raíz genealógica de carácter profético-escatológica: «estando en oraçión pidiendo a Dios con mucha eficacia le mostrase si R. ${ }^{\circ}$ de Valer estaua engañado le fue dho q. . $^{e}$ tenía herrores, y que después rogando

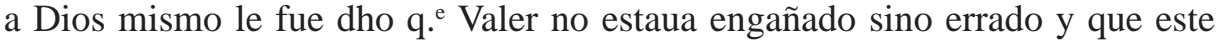
herror era por su culpa, porque engañado quiere dezir por otro, y herrado por sí mismo». ${ }^{22}$ En el propio documento se asegura que Camacho visitaba a un inquisidor sevillano de quien no se expresa su nombre: «a decir que hiciese alguna cosa diciendo que lo mandaba Dios»; en ocasiones, Dios le pedía a Camacho que viajase desde Jerez a Sevilla para visitar a este inquisidor e, incluso, que se alojase en su propia casa, como así ocurría. ${ }^{23}$ Por otro lado, cuando, como más adelante veremos, se detenga en el convento de la Concepción de Lebrija para ayudar, mediante revelación, a convencer a una monja hermana de la abadesa a no salir de su estado, se dirá aludiendo a él que «pasava por este Lugar un gran siervo de Nuestro Señor que iva a la ciudad de Sevilla a dar quenta a la Santa Ynquisiçión de sierto negocio que pasava en su Lugar de donde venía». En lo que es un nuevo testimonio de la colaboración de Camacho con la Inquisición

${ }^{21}$ A.H.N. Inquisición, leg. 2957/2. Testimonio en relaçión de lo que se a hallado en el sancto offiçio de la Inquiss. ${ }^{o n}$ de Seu ${ }^{a}$ contra Gomez Camacho, vz. ${ }^{o}$ de la çiudad de Xerez de la frontr. ${ }^{a}$, fol. 3v. La denuncia es un poco oscura, pues, al fin y al cabo, son demonios los que dicen que quemen a Valer. De cualquier forma, posteriores afirmaciones de Camacho permiten mantener la afirmación del desencuentro. Así lo piensa también Boeglin, M. 2007: 124.

${ }^{22}$ Ibídem, fol. 4v. A Boeglin, en su análisis de este documento, también le parece extraña la relación de Camacho con la Inquisición: «Sorprende, en efecto, la familiaridad del individuo con los inquisidores de entonces». Boeglin, M. 2007: 125.

${ }^{23}$ Ibídem, fol. $5 \mathrm{v}$.

Hispania Sacra, LXIV

129, enero-junio 2012, 141-186, ISSN: 0018-215-X, doi: 10.3989/hs.2012.005 
quien, en esa coyuntura, pasaba por Lebrija procedente de Jerez en dirección a la Inquisición de Sevilla. ${ }^{24}$

El hecho más preclaro y evidente de colaboración de Gómez Camacho con el Santo Oficio sevillano nos lo explicita el propio Bernardo de Toro, en su memorial al Inquisidor General don Bernardo de Sandoval y Rojas, cuando dice que entre los años 1549 y 1551 Camacho fue examinado espiritualmente nada menos que por el temible Inquisidor General y arzobispo de Sevilla don Fernando de Valdés, además de por los inquisidores sevillanos Pedro Díaz de la Plaza y Toribio Rojo, en la que no hallaron nada contra la ortodoxia del profeta cerrajero, todo lo contrario, fue inexplicablemente obsequiado por Valdés con una bolsa de doblones de oro, con los que compró una casa en Jerez, así como con la propia cruz pectoral del arzobispo, al propio tiempo que la Inquisición le ordenaba al cerrajero que abandonase su oficio «sino que se recogiese a su casa y ciudad de Gerez de la frontera y que allí prosiguiese su exemplar vida y se diese a su continua oraçión la qual aplicase por la intención de la Santa Yglesia Cathólica Romana». ${ }^{25}$

Copias de este memorial, que se sepa, tenemos tres: la guardada en el Archivo Histórico Nacional, la que incluye Pedro de Jesús María en su biografía de Hernando de Mata y la que inserta una monja anónima del convento de la Concepción de Lebrija en un volumen manuscrito en el que se narra la vida de Francisca de Vera, discípula espiritual de Gómez Camacho y segunda abadesa del convento de la Concepción de Lebrija que, si bien es muy parecido al de la biblioteca particular sevillana que antes hemos aludido, presenta notables diferencias; por ejemplo, respecto a esta relación de Gómez Camacho con la Inquisición que nos permite conocer un dato absolutamente extraordinario.

En el memorial original de Toro y Vázquez de Leca, conservado en el Archivo Histórico Nacional, al narrar el hecho excepcional ocurrido con el arzobispo Valdés, se dice en relación a Gómez Camacho que:

\footnotetext{
${ }^{24}$ Esta noticia procede de un códice en el que se inserta la vida de la abadesa que se conserva en una biblioteca particular sevillana: Códice de la Granada, que se titula: Vida y Milagros de Nra. Sta. Madre Doña Francisca de Vera, dignísima Abbadesa de este Religiosísimo conuento de la Immaculada Consepción de Nuestra Señora de la villa de Lebrija, con un traslado de la información de su vida y milagros fecha con comición del ordinario por el ilustríssimo y reverendíssimo señor cardenal de Roma Don Rodrigo de Castro y Quiñones, Arçovispo de Sevilla, firmada del notario y testigos. En este manuscrito no se cita directamente a Camacho, aunque en otro conservado en el propio convento lebrijano sí que se identificará con su nombre. Es interesante establecer las diferencias de ambos manuscritos, pues en el primero se procura evitar el nombre de Gómez Camacho y de su mujer Catalina Jiménez. En un futuro trabajo afrontaremos el cotejo de ambos manuscritos.

${ }^{25}$ Huerga queda estupefacto ante esta noticia y no parece darle mucho fundamento pues a su juicio la actitud de Valdés es aquí muy distinta a su personalidad: «Y, a fe, nos quedamos perplejos, sin atinar a discernir si esta imagen de Valdés es fantástica o real, si se trata de una ingenua estampa hagiográfica o de una treta tergiversadora». Huerga, A. 1988: 36. Ya veremos más adelante cómo esta actitud del célebre Inquisidor General puede tener una lógica.
} 
Eran tantas las marauillas que el Sr. obró por esta Santa Criatura que la Ynquisiçión le bino a dar por secretario para que le escriuiera vn padre muy graue de la orden de santo Domingo llamado fr. Domingo Graxales, por otro nombre el canario y el prior de la Cartuxa de Xerez los quales por su mano escriuieron muchas cosas diuinas y celestiales q. e el santo varón Gómez Camacho pronunciaua y deçía en la Oraçión y en raptos diuinos que tenía.

Cuando Pedro de Jesús María inserta, cuarenta y ocho años más tarde, este memorial en su biografía de Hernando de Mata, al llegar en la redacción a la altura de «el prior de la Cartuxa de Xerez» y tras un punto y seguido, continua así: «Este es el que descubrió la Seta de los alumbrados de Llerena, y las Heregías de Constantino y Cazalla, y de el Convento de San Isidro de Sevilla», tras lo cual prosigue tal y como está en el memorial guardado en la Inquisición. Pero, ¿qué significa esto? ¿Fue el prior de la cartuja jerezana, a la sazón secretario inquisitorial que daba fe de las revelaciones de Camacho, el «héroe» que descubrió semejantes atropellos a la ortodoxia católica? Esa es, al menos, aunque de una forma un tanto oscura, la sensación que transmite el monje basilio.

Sin embargo, en la tercera copia, inserta en el manuscrito, posiblemente preparado para su edición impresa, de la biografía de la madre Francisca de Vera, fechado también en 1663, la monja anónima que realiza esta biografía, que no cabe duda que sabe mucho de Gómez Camacho y de su mujer Catalina Jiménez, y que afirma que copia el memorial siguiendo a Pedro de Jesús María, cuando llega a la cita de fray Domingo Grajales «el canario» continua diciendo que:

No es posible en este breue compendio desir lo mucho que en este conu. ${ }^{\text {to }}$ ay de noticias de este $\mathrm{S}$. ${ }^{\text {to }}$ varón [Gómez Camacho] que será salvo del intento y sus mayores grandesas están recogidas en la inquisiçión de Sevilla y otras, solo digo que por su oraçión se descubrió la seta de los Alumbrados de Llerena y las heregías de Constantino y Casalla y del conut. ${ }^{\circ}$ de san Ysidro de Sevilla, todas se escriuieron por este secretario como lo sita el dicho libro porque se las pronunçiaua el S. ${ }^{\text {to }}$ varón Gómez Camacho y desía en su oraçión y en raptos divinos que tenía. ${ }^{26}$

Las preguntas devienen lógicas: ¿Fue Gómez Camacho quien delató a la Inquisición, amparado en sus revelaciones, no solo a Rodrigo de Valer sino también a los alumbrados llerenenses y, sobre todo, a la trama luterana sevillana en la que se incluían Egidio, Constantino y los jerónimos de San Isidoro del Cam-

\footnotetext{
${ }^{26}$ Libro de la vida y Milagros de nra santa madre Doña fransisca de uera dignissima abba. de este Religioso conu. ${ }^{\text {to }}$ de la inmaculada consepçión de nra. S.ra de la villa de lebrixa $i$ sacada de diuersos escritos, que se hallaron en el archiuo del mesmo conu.to, y de testigos de vista, como fueron algunas religiosas que la uieron y trataron. Por una indigna monga de su mesmo conu. ${ }^{\text {to }}[+:$ al margen: Año de 1663] con un traslado de la información de sus milagros, que se hiso con comisión del ordinario por el Yllm. ${ }^{\circ}$ S. ${ }^{r}$ cardenal de Roma Don Rodrigo de Castro Arçobispo de Sevilla, firmada del Notario y testigos. Convento de la Purísima Concepción de Lebrija, Mss., pp. 20-30. Agradezco la amabilidad por la facilidad prestada en su consulta a la Madre Abadesa Sor María José Sánchez.
}

Hispania Sacra, LXIV

129, enero-junio 2012, 141-186, ISSN: 0018-215-X, doi: 10.3989/hs.2012.005 
po? Pero aún hay más, ¿Fue Gómez Camacho quien delató a los Cazalla lo que, si de veras fuera cierto, nos revelaría una conexión clara, que ya intuíamos por la conocida visita de Egidio a la ciudad del Pisuerga, entre los dos conventículos reformistas de Sevilla y Valladolid? O, quizás, ¿Es un añadido a lo estrictamente expuesto en el memorial de 1615, por parte de Pedro de Jesús María, que en realidad no deja claro quién es el «héroe» y que nuestra monja anónima interpreta, al «heroizarlo», que tal personaje es Gómez Camacho?

A tenor de los hechos que hemos presentado: las conexiones Camacho-Valerreformados; las relaciones Camacho-Inquisición, el profundo conocimiento que en el convento de Lebrija - en el que Camacho está enterrado y donde se veneraba como a un santo- se tenía de sus hechos y la seguridad de la monja anónima que los relata, nos llevan a pensar que esa labor de delación de Camacho pudiera ser cierta y nos explicaría la actitud bondadosa para con el cerrajero-profeta del temible Inquisidor General Valdés. Sin embargo, hay un hecho que juega en contra de la afirmación de la monja lebrijana, Gómez Camacho murió en 1553, mientras que las primeras detenciones de luteranos sevillanos y vallisoletanos se producen en 1558 y los hechos alumbradistas llerenenses tienen lugar entre 1570-79. En su descargo diremos que esta detención obedece a una coyuntura concreta, la actividad proselitista del grupo protestante sevillano se había desplegado desde hacía diez o doce años antes de la detención masiva, es decir, en torno a 1547, aunque si atendemos a las actividades de Rodrigo de Valer, esta fecha habría que retrasarla a la década de $1520 .{ }^{27} \mathrm{Si}$ Camacho hubiese sido un delator-visionario desde esta fecha, resultaría que llevaba a la hora de su muerte más de treinta años pasando información a la Inquisición sevillana.

Lo cierto es que esta vía de penetración de la reforma, esta rama de la disidencia religiosa cuya base era el evangelismo, por su similitud evangélica, entroncada en una espiritualidad profética basada en la videncia, el profetismo y la comunicación con la divinidad, quedó cortada por las hogueras inquisitoriales sevillanas de 1558-62 encendidas por el propio arzobispo de Sevilla e Inquisidor General Fernando de Valdés, aunque esto no fue óbice para que el modelo de espiritualidad que Camacho había sembrado en Jerez y Lebrija pasase y echase raíces también en Sevilla.

El convento de la Purísima Concepción de Nuestra Señora de Lebrija y su abadesa Francisca de Vera

En Lebrija, y sin perder la conexión con Jerez, funcionaba un grupo de discípulos de Camacho que presentaban ciertas semejanzas espirituales -raptos, vi-

\footnotetext{
${ }^{27}$ Castrillo Benito, N. 1991: 135-136. Sí que pudo haberlo hecho en el caso de Egidio que fue acusado en torno a 1550 y se retractó el 21 de agosto de 1552.
} 
siones, profetismo- con su maestro. ${ }^{28}$ Parece que el centro de este conventículo fue el convento de la Purísima Concepción de Lebrija, fundado por el arzobispo fray Diego de Deza y que llevó a cabo su provisor Sancho de Matienzo el día de San Agustín 28 de agosto de 1519. ${ }^{29}$ Para ello fueron desemparedadas ocho «santas Mujeres» quienes deseosas de vivir en recogimiento y obediencia «se avían recojido en un emparedamiento en la capilla del maestro Vela que está en la Yglesia mayor de esta dicha villa». Tras la apertura del emparedamiento, fueron trasladadas en solemne procesión a la ermita de San Sebastián, lugar en el que se fundó el convento y en el que Matienzo les dio el hábito en ese día de agosto de 1519 y les presentó a su abadesa, traída del convento de Las Dueñas de Sevilla, Leonor de Cabrera, con su vicaria, Isabel de Escoto. ${ }^{30}$ Los nombres de las fundadoras son: Isabel Vidal; Joana Vidal, su hermana; Antonia de San Francisco; María de los Ángeles; Margarita de Torres; Catalina de Ortega e Isabel Xarana. La vida de casi todas estas mujeres está plagada de acciones sobrenaturales, visiones, comunicaciones divinas y profetismo, pero sobre todas destacó Francisca de Vera (1514-1574), su segunda abadesa. ${ }^{31}$

${ }^{28}$ En el memorial de Bernardo de Toro, ya citado, se dice de Camacho que pronunciaba «cosas diuinas y celestiales» en la oración y en los raptos divinos que tenía «unas vezes hablando de Dios y otras con Dios, y otras en que el mismo Dios hablaua por él». Vid. Jesús María, P. de. 1663: 4v.

${ }^{29}$ Biblioteca particular de Sevilla. Códice de la Granada s/f. Memorial de la fundación de este conuento de Nra. Sra. de la Ymmaculada Consepción de la villa de Lebrixa y Traslado de las vidas de las fundadoras y de nuestra santa madre y Abbadesa Doña Francisca de Vera, segunda Abbadessa que uvo en este dicho conuento. Toro alude en su memorial a este convento y a cuatro monjas que habían conocido a Camacho y su mujer, además hace hincapié en cómo el convento se convierte en una especie de fábrica de reforma espiritual que, a su vez, es exportada al arzobispado: «asimismo darán larga cuenta, quatro Monjas que oy viuen en el Convento de la Concepción de la dicha villa de Lebrixa, que conocieron y trataron al dicho Padre Camacho, y a su muger Catalina Ximénez, que son las que reformaron este dicho Convento, y hasta oy es su Recolección: de suerte, que de todo el Arçobispado de Seuilla, se embían a él Monjas delinquentes, y vuelven reformadas a sus casas en breve tiempo, y del dicho Convento se lleuan por Abadesas Monjas, para reformar otros Conventos del Arçobispado, y las demás Monjas de allí dirán por relación, y tradición, que de estos tienen». Vid. Jesús María, P. de. 1663: 4v-5r.

${ }^{30}$ «luego traxo por Abbadessa a la señora doña Leonor de Cabrera del convento de Las Dueñas de Sevilla y a Ysavel de Escoto por Vicaria de este dicho conuento». El duro y terrorífico Matienzo llevó al convento nada menos que a las temibles «Sayonas» que le habían servido de instrumento de su terror y represión en el convento homónimo de la Concepción de San Juan de la Palma en Sevilla. Sospechamos que sean las mismas que cita Juan Gil como reformadoras del convento concepcionista sevillano, aunque no coincide el nombre de Escoto ya que Gil afirma que se llamaba Leonor y no Isabel. Vid. Gil, J. 2000. Los conversos y la Inquisición sevillana: vol. II, 69-70 Sevilla. Sobre el convento concepcionista de Sevilla vid. Fraga Iribarne, M. L. 1993. Conventos femeninos desaparecidos. Arquitectura religiosa perdida durante el siglo XIX en Sevilla: 185-203 Sevilla.

${ }^{31}$ Los datos referidos a Francisca de Vera proceden de una vida manuscrita de la misma inserta en el citado Códice de la Granada, que se titula: Vida y Milagros de Nra. Sta. Madre Doña Francisca de Vera, dignísima Abbadesa de este Religiosísimo conuento de la Immaculada Consepción de Nuestra Señora de la villa de Lebrija, con un traslado de la información de su vida y milagros fecha con comición del ordinario por el ilustríssimo y reverendíssimo señor cardenal de Roma Don Rodrigo de Castro y Quiñones, Arçovispo de Sevilla, firmada del notario y testigos. Asimismo lo completamos, con su

Hispania Sacra, LXIV

129, enero-junio 2012, 141-186, ISSN: 0018-215-X, doi: 10.3989/hs.2012.005 
De padres jerezanos, Nuño de Vera y doña Clara de la que «su alcuña no se halla escrita», lo que hace sospechar su procedencia conversa, tuvo dos hermanas, doña Beatriz y doña Ana de Vera, ambas monjas también en el mismo convento, y tuvo dos hermanos, don Pedro y don Francisco de Vera. Sus padres entregaron a Francisca al convento cuando esta cumplió los dos años. Según su biógrafa, pronto Dios dispuso que su maestra fuese la mejor: la Virgen María, de manera que como fruto de ello «fue antes espiritual que carnal», «antes santa que muger y perfecta religiosa». ${ }^{32}$ Fue una precoz espiritual y virtuosa de la oración «antes de saber formar palabras era maestra de oración», ante la lectura de libros de oración se turbaba, se establecía una comunicación, una unidad de acción entre maestra, la Virgen, y su discípula, la futura abadesa Vera.

Llevaba desde la más tierna infancia el ayuno a rajatabla, algo que iba a persistir durante toda su vida. Destacó en su pobreza externa, nunca estrenó una toca nueva siempre vistió una vieja y raída y mientras que la lavaba le prestaban otra; la camisa que vestía estaba remendada y desechada de otras. Algo parecido ocurría con el hábito, jamás estrenó uno nuevo, siempre vistió los desechados por las monjas. Los bienes que poseía en su celda se reducían a una pequeña caja con los libros de cuentas del convento, tampoco quiso nunca una ayuda económica de sus deudos. Pretendió imitar la pobreza de Cristo. La penitencia que ofrecía en las cuaresmas era muy curiosa, se iba al patio del convento y masticaba ramas de olivo «por gustarle la hiel que su esposo y señor gustó en la cruz». Llevó siempre en su cuerpo un cilicio «con una empleita de esparto a la sintura que cogía medio cuerpo». Aún más curiosa, y dura era la práctica que realizaba los viernes: «se ponía un ecce homo que era un hiscal de esparto con unos nudos echados que puesto por la garganta le crusava por el pecho y por mucho que lo encubría no se dejava de parecer». Se disciplinaba con una disciplina de hilo de alambre, lo hacía de una forma muy continuada de manera que «quando se quitava del lugar donde avía hecho la disiplina le hallavan lleno de sangre».

Criada en el convento desde su niñez, parece que Vera tuvo una mediana formación, «entendía la gramática». Era una excelente cantora y organista. Poseía dotes para la organización y la administración financiera, por ello siempre llevó las cuentas del convento. Tras la profesión fue portera de la puerta reglar, oficio que no dejó hasta su nombramiento como abadesa. Aparte de ello se dedicó a la enseñanza de las novicias, esta vez por revelación divina: «Díjole Nuestro Señor

cotejo, con Libro de la vida y Milagros de nra santa madre Doña fransisca de uera..., guardado en el convento lebrijano y al que hemos aludido con anterioridad.

${ }^{32} \mathrm{Si}$ nació en 1514 y entró en el convento con dos años tuvo que ocurrir esta entrada en 1516, cuando aún no se había fundado el convento, cuya fundación es de 1519. Por tanto, o entró en el emparedamiento o entró con cinco años, pues las fechas parece que son correctas si nos atenemos a los datos que aporta la biógrafa quien nos dice que murió: «a la una de la noche día martes a 21 de Diciembre, día del glorioso Apóstol santo Thomé del año de 1573 [al margen: «corregido año de 1574]......aviendo sido Abbadesa treinta años, murió de sesenta». 
a esta sierva suya que quería Su Magestad que criase al Niño Jesús». Vera no lo entendió en un primer momento puesto que, en su relación con Jesucristo, en sus visiones mentales por medio de la oración interior, concebía a la divinidad como un hombre no como un niño: «porque le considerava en su alma como hombre en su Pasión»; sin embargo, tuvo una revelación a través de otra persona, «un alma santa», que la biógrafa no revela, que le aclaró el deseo divino: «quería le sirviese en criar las nueuas planticas de la religión, siendo maestra de nouiçias». No sería extraño que esa alma santa que le aclaró el deseo divino tuviese que ver con Gómez Camacho y su mujer Catalina Jiménez.

Francisca de Vera, por tanto, debía reformar la espiritualidad de su convento comenzando el trabajo con las novicias, a las que exhortaba a la devoción a la Inmaculada: «os encargo mucho que seáis mui devotas de la Sacratísima Virgen Nuestra Señora y de su Purísima Consepción». Llevó a cabo fielmente su obligación y tuvo un gran éxito «pues todas las que recibió fueron de vida mui exemplar». En esta enseñanza empleaba gran parte de la noche. Exhortaba a sus novicias a la mortificación y a la penitencia, les realizaba pláticas de subido tono espiritual que mantenían en vilo a sus alumnas, hasta el punto de que la abadesa fundadora, Leonor de Cabrera, solía preguntarse: «qué hará doña Francisca con estas hormiguitas».

Todos estos esfuerzos de Francisca de Vera pronto fueron recompensados por Dios. La primera recompensa fue la conversión de su hermana, doña Ana de Vera. Fue intermediario de ese don divino el maestro de la propia Francisca, Gómez Camacho. No cabe duda de que Vera fue discípula espiritual de Gómez Camacho y de su mujer Catalina Jiménez, así nos lo afirma su biógrafa:

fue tenido por s. ${ }^{\text {to }} \mathrm{y}$ su s. ${ }^{\text {ta }}$ mujer la m. ${ }^{\text {e }}$ Cathalina Ximénes se le fue dado su mesmo espíritu con diferençia que ella acudía al gouierno de su casa y el s. ${ }^{\text {to }}$ Camacho no avía de haser otra cosa que estar en oraçión, tuvoles mi s. ${ }^{\text {ta }} \mathrm{m} .{ }^{\mathrm{e}} \mathrm{D} .{ }^{\mathrm{a}}$ franc. ${ }^{\mathrm{a}}$ de vera particular amistad porque se comunicavan sus espíritus y desde Xeres se gouernaua la s. ${ }^{\text {ta }}$ por cartas. ${ }^{33}$

Ana de Vera era religiosa en el mismo convento que su hermana, aunque siempre estuvo descontenta con ello de manera que se intentó desligar del mismo contrayendo matrimonio. Había pedido las pertinentes bulas a Roma. Francisca rezaba continuamente para que su hermana entrara en razones y no abandonase la vida conventual, desesperaba llegando un jueves en la noche, en plena oración, a increpar a Dios de esta manera: «Señor, si tú eres Dios muéstrame cómo te mostraste a las tres Marías quando yvan al sepulcro». Según la

\footnotetext{
${ }^{33}$ Libro de la vida y Milagros de nra santa madre Doña fransisca de uera..... Convento de la Purísima Concepción de Lebrija, Mss., p. 30. El gobierno espiritual a través de cartas de los miembros del grupo que se formaría en el convento, lo seguirían practicando los seguidores de Camacho: Rodrigo Álvarez, Hernando de Mata y Bernardo de Toro, de los cuales el citado Códice de la Granada conserva cartas enviadas tanto al convento lebrijano como al de mínimas de Jerez.
}

Hispania Sacra, LXIV

129, enero-junio 2012, 141-186, ISSN: 0018-215-X, doi: 10.3989/hs.2012.005 
biógrafa anónima del manuscrito que seguimos, esto lo dijo aturdida, pues al sucederle «cosas tan altas» recelaba si procedían realmente de Dios. Pero Dios la oyó, pues:

pasava por este Lugar un gran siervo de Nuestro Señor que iva a la ciudad de Sevilla a dar quenta a la Santa Ynquisiçión de sierto negocio que pasava en su Lugar de donde venía y pasando por aquí llegando al fin de las casas, que es el Fontanal viejo, que así le llaman a una fuente de buen agua que está allí, le detuvo Nuestro Señor no permitiendo pasara adelante hasta que hiciera esta obra de la conversión de doña Anna de Vera, y así se lo dio a entender en su alma y el santo venía diciendo: qué tenéis Señor con los hombres que tanto los amáis.

Este gran siervo era Gómez Camacho quien volvió a Lebrija y entró en contacto con el mayordomo del convento, Francisco González, «el cuál era mui santo y a quien Nuestro Señor hiso particulares misericordias». ${ }^{34}$ Ambos fueron al torno del convento y pidieron a la abadesa Leonor de Cabrera que les permitiese hablar con Francisca de Vera. Camacho se retiró a descansar y González advirtió a Vera que, por mandato del profeta visionario, se confesase y comulgase. Al día siguiente, viernes, llegó Camacho nuevamente al convento. La abadesa buscó a Vera a la que dijo: «Doña Francisca, Camacho y Francisco Gonçáles la llaman, levántese y vaya luego». Admirada de que la abadesa le permitiera salir del capítulo corrió en su búsqueda:

Este siervo de Dios que venía a ser el medio para esta gran obra que Su Magestad quería hazer en Doña Anna de Vera, se entiende hablava el espíritu de Nuestro Señor Jesuchristo en él y según sus efectos que con sus palabras obrava davan muestra de ser esto verdad, mas la santa madre teniendo alguna duda y temor dijo estas palabras: Señor si tú eres Dios el que hablas en esta criatura y por su voca dame a mi hermana en testimonio de esta verdad; y entrando ella por la escala con mucha humilldad y reverençia se echó a los pies del santo y siervo de Nuestro Señor, el cuál luego le habló y le dijo: en gran peligro está la Ygleçia con mui poquito se cumplirá el deseo de los malos, raçón es que por una parte gane lo que por otra se pierde. Advierte Francisca que el espíritu de Jesuchristo es el que te habla, pediste a tu hermana en testimonio, dártele quería mas esperaua que te dispusieses y lo pidieses, esta tu hermana era muchacha y descuidose pero yo volveré su coraçón y sus quereres, levántate y llámala.

Francisca de Vera le aseguró a Camacho que su hermana Ana no vendría, pero este volvió a repetirle: «levántate y llámala». Francisca fue a llamarla pero Ana no quiso ir, increpó a su hermana y a Camacho acusándolos con fina agudeza de lo que realmente eran: «qué me quieren estos ypócritas alumbrados». Ana aducía que, por muy santo que fuese Camacho, no podría convencerla para que no tomase el estado del matrimonio. Lo tenía todo a su favor: era menor de edad

\footnotetext{
${ }^{34}$ Mientras que esto dice del mayordomo Francisco González el manuscrito de la biblioteca particular sevillana, el del convento lebrijano dice: «un s. ${ }^{\text {to }}$ varón llamado fran ${ }^{\text {co }}$ gonsales íntimo hijo de este s. ${ }^{\text {to }}$ gomes Camacho y de mi s. ${ }^{\text {ta }}$ m..$^{\text {e }}$. ${ }^{\text {a }}$ fran. ${ }^{\text {ca }}$ de uera».
} 
cuando profesó, las bulas de dispensa de Roma estaban a punto de llegar y, por último, tenía un hombre dispuesto a casarse con ella. Camacho, cuando Ana llegó al locutorio, comenzó a hablarle no como le hablaría un cerrajero, sino como lo haría un teólogo o, mejor, como hablaría el mismísimo Dios bíblico y terrorífico de Abraham: «maledicti qui declinant a mandatis tuis». ${ }^{35}$ A continuación le comunicó lo que Dios le ofrecía y, cuando Ana lo rechazó, dijo: «Francisca, si esta es tu hermana no se enmienda, yo haré en ella un castigo más que a dos de este lugar». Camacho actuaba en ese momento en el locutorio del convento lebrijano como un médium, no era él quien hablaba sino Dios a través de él. Ana se afligía y lloraba absolutamente contrita, según narra la biógrafa en esta conversación entre Ana y Dios-Camacho:

Señor alcanzaré perdón de mis pecados. Respondiole el Señor: al coraçón sí alcansarás de los que jimieres, como está escrito no me acordaré más de ellos. Y más le dijo: perdonados te son de los que tuviste contrición, joh, si me amases como te Amo!, date a la oraçión y llegate a mí por el sacramento, esta disposición te durará dos días y si te dispones se te darán los socorros más que los comunes.

¡Qué impresión tan grande se llevarían las hermanas, en especial Ana, cuando oyó a Dios, seguramente con voz impostada, a través de la boca de Camacho! La biógrafa la describe postrada en el suelo fuera de sí, su hermana Francisca le pidió que se levantase, Ana declinó la invitación: «déjeme señora». Camacho la reconfortó y se despidió, Ana corrió al coro delante del Santísimo Sacramento «y desde esta ora olvidó todas las cosas del mundo y fue su alma favorecida y regalada con soberanos júvilos y consuelos del çielo por espacio de dos años, que fueron los dos días que Nuestro Señor le prometió». Pasados los dos años prometidos volvieron las pasiones y tentaciones a la conciencia de Ana que fueron vencidas por la oración de su hermana Francisca hasta que murió.

La práctica espiritual de Francisca de Vera estaba muy cercana a lo que conocemos de Camacho y, en general, a la práctica visionaria, alumbrada si queremos, del prototipo de monja iluminada barroca. Al igual que su maestro, también escribió tratados espirituales: «un tratado que le escriuió que le intitulaba: Soliloquium diuinum, tan lleno de caridad y amor de Dios y del próximo y con lugares de la escriptura que el más aventajado teólogo tuviera mucho en qué reparar por la saviduría de sus palabras y alteza de su espíritu», además de otros tratados de oración y de amor de Dios. ${ }^{36}$

\footnotetext{
${ }^{35}$ Salmo 118: Malditos los que se apartan de tus mandatos. Camacho, tal como su padre espiritual, Francisco de Paula, no sabía latín pero esto no fue óbice para hablarlo. Lucas de Montoya nos afirma que Paula hablaba en lengua latina «Cosa no menos marauillosa, pues nunca aprendió letras humanas, ni diuinas, sino aquellas que el Espíritu Santo le enseñó, con que de ordinario citaua la sagrada escritura, como el más docto predicador». Montoya, L. de. 1619: 132.

${ }^{36}$ Este tratado se lo dedicó Vera a su discípulo espiritual, y miembro de su grupo de espiritualidad, el confesor y visitador de monjas del arzobispado de Sevilla Bartolomé García del Ojo. Sobre la visión
} 
Debió participar desde muy pronto en el conventículo de la gente espiritual dirigido por Camacho. Parece que eso no gustó al visitador de monjas del arzobispado, quien un buen día la envió llamar al coro bajo del convento. Acudió obediente la monja y el visitador «con grande rigor y fuerça le mandó no tratase con unas personas que para ella eran de grande consuelo y ayuda en su espíritu por ser las personas mui santos y espirituales». A pesar de la calidad espiritual de esas personas, el visitador ordenó a Vera su repudio. Esa decisión la censura la biógrafa: «como en las religiones nunca falta quien sienta no vien de lo bueno, aquí no faltó quien sintiera mal de esta comunicación». Francisca obedeció sumisa aunque, al parecer, por poco tiempo: «nunca más les trató hasta que Nuestro Señor dispuso otra cosa».

Este grupo de espirituales estaba formado por Gómez Camacho y los demás miembros de su conventículo espiritual y a través de éste se confirmó la predilección de Dios por Francisca de Vera. Cuando su hermana Ana muere fue atendida en confesión por Benito Ximénez que «era también hijo del p. ${ }^{e}$ Camacho», confesor del convento, quien en sus oraciones siempre pedía a Dios la salvación de sus padres, como recompensa a su atención a Ana de Vera en su muerte Dios se lo concedió. Todo ello se supo por medio de «una sierva de Nuestro Señor a quien Su Magestad tratava mui familiarmente». Fue así como Dios lo expresó a la citada sierva: «dile a Benito Ximénes que por esta obra que a hecho que me a sido mui agradable le concedo la salvación de sus padres que siempre me pide». ${ }^{37}$ Francisca agradecida por lo ocurrido con su hermana perseveró en sus prácticas ascéticas y oraciones. Dios estaba tan prendado de la hermosura y virtud de Francisca que, además de los dones que le proporcionaba a solas, le hacía llegar por «tersera persona» su favor, de manera que «le solía imbiar recados disiendo: desilde a doña Francisca que resiva de mi parte más de mill encomiendas y que toda la tengo dotada a mi voluntad y no sé plaser que hacerle».

Puede apreciarse que el grupo de Camacho, convertido en esas terceras personas, fue convenciendo a Francisca, y a otros personajes cercanos al convento,

clásica de la monja barroca Vid. Álvarez Santaló, L. C. 2005. «Palabra de Dios, pluma de claustro. El discurso literal de la divinidad y sus adyacentes en la revelación visionaria barroca», en M. Vitse (ed.). Homenaje a Henri Guerreiro: 169-227. Madrid: Iberoamericana-Vervuert. Álvarez Santaló, L. C. 2002. «La aparición visionario conventual: anatomía sugerente del «paisaje con figuras» revelado (siglos XII-XVII)», en D. González Cruz (ed.). Ritos y ceremonias en el Mundo hispánico durante la Edad Moderna: 43-90. Huelva: Universidad de Huelva, 2002. Álvarez Santaló, L. C. 2003. «Fr. Leandro de Granada: divulgación «científica» de las técnicas visionarias. El imaginario religioso a las aulas lógicas», en M. L. López-Guadalupe Muñoz; A. Lara Ramos; A. L. Cortés Peña (coord.). Iglesia y sociedad en el Reino de Granada (ss. XVI-XVIII): 265-310. Granada, 2003. Sánchez Lora, J. L. 1998. Mujeres, conventos y formas de la religiosidad barroca. Madrid: FUE.

${ }^{37}$ Según el manuscrito conservado en el convento lebrijano, esta sierva que comunicó al confesor la concesión divina fue la mujer de Camacho: «le imbió a desir con la m. ${ }^{e}$ Cathalina Ximénes, la muger el s. ${ }^{\text {to }}$ gomez Camacho». 
como los confesores, de esta predilección y de que su propia comunicación con la divinidad era muy verdadera.

\section{Francisca de Vera y los ejercicios de SAn Ignacio}

En 1544, a los treinta años de edad, Francisca fue elegida abadesa del convento, había llegado su momento, ahora sería ella la vidente, la que se comunicaría con la divinidad de una forma clara y rotunda «Tuvo nuestra señora madre familiarísimo trato con Nuestro Señor y hablávale mui de ordinario en sus visitas divinas», así lo había comprobado y así se lo hicieron saber Camacho y su conventículo; «tuvo espíritu de profecía», dice su biógrafa, fue muy querida de sus monjas, severa con la regla pero tolerante con nimiedades, tras la dureza de la «Sayona», de Leonor de Cabrera la primera abadesa, su gobierno debió parecer angélico, fue tanta la fama que comenzó a correr por Lebrija que la gente acudía a oír, al no poder predicar, su lectura en el coro: «en la contemplación de completas los sábados que se canta la Salve acudía gente a la Ygleçia como si fuera sermón porque leía con tanto espíritu y devosión que fervorisava los coraçones de los oyentes y se consolavan mucho de oírla». A partir de su prelatura el convento debía ser conocido por su santidad en todo el orbe cristiano, el mismo Dios le comunicó en una ocasión que «desde los montes Perineos acá no avía otro conuento de que más se agrade y sirva que de este».

La espiritualidad de Francisca, basada en el profetismo y la revelación procedente de Gómez Camacho, conocerá ahora un entronque con la espiritualidad jesuita que será también una espiritualidad más intimista y de inclinaciones místicas antes de que la Compañía, en su avance hacia el ascetismo, realice el giro contrarreformista. ${ }^{38}$ Narra la biógrafa anónima de Vera que pasaron por Lebrija dos jesuitas, el padre Cristóbal López de Mendoza y el padre Carvajal, allí se detuvieron varios días dedicados a la predicación, confesión y pláticas espirituales. En ese tiempo les llegó la noticia de la santidad de la abadesa del convento de la Concepción y quisieron conocerla. Acudieron al convento y pudieron comprobar in situ la virtud de la monja y «quedaron admirados de su santa conuersaçión». Asimismo, a Francisca les parecieron aquellos dos hombres dos apóstoles y quiso confesarse con uno de ellos «y tratarle negosios de su espíritu». Se le unieron algunas de sus monjas, de sus dirigidas, «de las más hijas de la santa Abbadesa». Los jesuitas les dieron «los exerçiçios espirituales que usa la Compañía y la orden de exersitarse en ellos, y así lo hasían».

\footnotetext{
${ }^{38}$ Martínez Millán, J. 1998. «Transformación y crisis de la Compañía de Jesús (1578-1594)», I religiosi o corte. Teologia, Politica e Diplomazia in Antico Regime. Atti del seminario di studi Georgetown University a Villa «Le Balze». Fiesole, 20 ottobre 1995: 101-129. Roma: Bulzoni.
}

Hispania Sacra, LXIV

129, enero-junio 2012, 141-186, ISSN: 0018-215-X, doi: 10.3989/hs.2012.005 
Las monjas lo aceptaron encantadas de manera que cuando terminaban el cumplimiento de sus obligaciones comunitarias: «el demás tiempo gastavan en oraçión, confesiones y comuniones y todas guardavan silençio y solo tratavan con la santa Abbadesa». Se formó así un conventículo de monjas en torno a la abadesa, que practicaron la nueva forma de oración de los jesuitas con sus ejercicios espirituales. Sin embargo, en los conventos siempre está el demonio ojo avizor para minar la armonía. Francisca «tuvo aviso en su espíritu», de que el demonio preparaba una estrategia para formar el temido escándalo en la comunidad. Aprovechando este nuevo grupo dentro del convento y su relación con los jesuitas, tres o cuatro religiosas se escandalizaron y llegaron a creer que la abadesa Vera con las demás monjas de su conventículo «querían dar la ovediençia a aquellos padres, y así se determinaron y de hecho lo hisieron de escreuir al prelado que en aquella ocasión lo era el licenciado Luzero». ${ }^{39}$

El visitador de monjas no lo dudó y se dirigió a Lebrija para entrevistarse con la abadesa, que se defendió de las acusaciones, pero Lucero no quiso oírla y llegó, incluso, a pedir a los jesuitas que abandonasen inmediatamente la villa, cosa que cumplieron raudo. Francisca quedó, por el momento, de abadesa aunque Lucero la obligó a consultar cualquier decisión a una monja anciana llamada María Lobo, a la que se sometió enteramente Francisca. A los pocos días, en la fiesta de San Pedro, llegaron a la puerta del convento dos monjas enviadas por el prelado «la una para presidenta y la otra por compañera»; asimismo, quedaba suspendida la abadesa de sus funciones. Vera obedeció. Esa actitud, los parabienes que la presidenta enviaba al prelado y una enfermedad de este, que achacó a su comportamiento con la abadesa, llevó al visitador a restablecer a Francisca en el gobierno del convento y a mandar a las tres o cuatro monjas delatoras que pidiesen perdón a Vera, cosa que hicieron con humildad. Fue día de júbilo en el convento e, incluso, en toda Lebrija en la que el alcalde era el propio hermano de Francisca: «quedó el conuento consoladísimo y alegre y el pueblo también y con nueva fe y estima de la santa Abbadesa».

\section{El DON DE CRIAR ESPíRITUS DE FRANCISCA DE VeRA y LA CONGREGaCión de las Santísimas Misericordias}

Los confesores del convento fueron miembros del conventículo espiritual que Gómez Camacho instituyó y participaron de sus características alumbradas, por ser coetáneos o por herencia espiritual, a través de Francisca de Vera. Conocemos a Rodrigo Álvarez, antes de su traslado a Sevilla para ingresar en la Compañía de Jesús, Benito Ximénez, Bartolomé García del Ojo (+1598), que

\footnotetext{
${ }^{39}$ Según el manuscrito del convento lebrijano, fue Gómez Camacho quién desde Jerez supo en su espíritu lo que sucedía y ordenó a Vera que despidiera a los jesuitas «y que no se confesasen y asistiesen en este exersiçio».
} 
fue visitador, y Antonio Sánchez del Ojo sobrino del anterior y a quien sucedió como visitador de monjas del arzobispado «que con el mesmo espíritu de su tío y con gran deseo del bien de las almas governó este conuento quarenta años y aun se dijo dél, un siervo de Nuestro Señor, que este gran varón avía reseuido el espíritu doblado como otro Eliseo y así por intersesión de nuestra santa madre este conuento a sido governado por varones santos y de particulares vidas pues jamás an faltado desde que la santa faltó».

Algunos confesores fueron hijos espirituales de Francisca de Vera. A pesar de eso, la abadesa los respetó y obedeció como era su obligación: «Fue ovedientísima a sus confesores y aunque eran sus hijos de espíritu y criado en toda virtud, les tenía grande respeto por ser sus padres espirituales». La propia biógrafa nos da cuenta de que el don más sobresaliente que Dios otorgó a Vera fue su capacidad docente «Tuvo don de enseñar», una docencia muy especial: «de este tan maravilloso de criar espíritus». Destacaron en el tiempo de Vera dos de esos confesores:

siendo tan obediente y sujeta a sus confesores como queda dicho, fue maestra de ellos así del Padre Benito Ximénez como del señor visitador y doctor el Padre Bartolomé García del Ojo, varón santísimo y tan sujeto a la santa madre Abbadesa que sin su consejo no hacía ni disponía en negocios de su alma ninguna cosa.

Según la biógrafa, García del Ojo no hacía nada relativo a cuestiones espirituales sin consultar con la abadesa pues era «varón santísimo y tan sujeto a la santa madre Abbadesa que sin su consejo no hacía ni disponía en negocios de su alma ninguna cosa». Al parecer, también disfrutó de visiones, visitas de la divinidad. Un día, consagrando en la misa, se le apareció Cristo «aviertas las llagas y virtiendo sangre le dijo estas palabras: Vesme aquí todo para ti, ¿Qué más quieres que te dé?»; sin embargo, nada de esto hubiese sido posible sin la intervención de su maestra, Francisca de Vera: «Esta y otras mui particulares mercedes alcanzó este siervo de Nuestro Señor por medio de su santa maestra a quien tenía por madre como de verdad lo fue en todas ocasiones».

Además de estos confesores, entre sus discípulos estuvieron las monjas de su convento, estas «hijas espirituales», todas ellas altamente virtuosas y de parecida trayectoria que Francisca, especialmente fueron cuatro: María de Valer (+1586), quien le sucedió como abadesa y que pudiera ser hija de Rodrigo de Valer ${ }^{40}$ Ana Rodríguez, la sucesora de Valer en la dirección del convento, quien «era mui hermana y particular hija en espíritu», Beatriz de la Magdalena y Luisa de la Cruz quien profetizó el orden de la muerte de algunos de nuestros protago-

\footnotetext{
${ }^{40}$ Rodrigo de Valer tuvo siete hijos: Leonor Méndez Marmolejo, Beatriz Marmolejo, María de Valer, Antón Quebrado, Baltasar Marmolejo, Juana Méndez Marmolejo y Francisco Marmolejo. María de Valer hizo testamento en 1542 aunque era menor de edad; si bien cuando murió su madre en 1534 tenía una edad comprendida entre 14 y 25 años, Vid. Gil, J. 2005: T. II, 739-773.
}

Hispania Sacra, LXIV

129, enero-junio 2012, 141-186, ISSN: 0018-215-X, doi: 10.3989/hs.2012.005 
nistas: el primero, ella, luego el visitador Bartolomé García del Ojo y, por último, una hermana, cosa que ocurrió pues «salió de esta vida en 14 de diziembre octaua de La Simpecado en el año de 1597, y de allí a diez meses murió el señor visitador y después, mes y medio, la señora Abbadesa Anna Rodrigues y pasado otro mes la hermana San Joseph, monja del mesmo conuento, con que se vido cumplido todo lo que la sierva de Dios dijo».

Este grupo de cinco monjas, dirigidas por Francisca de Vera, formaban parte de un círculo espiritual muy particular organizado por Gómez Camacho que se denominó Congregación de las Santísimas Misericordias, a la que también pertenecieron los confesores, que se reunían todas las semanas a horas prefijadas «p. ${ }^{\text {a }}$ platicar y oír a nra. S. ${ }^{\text {ta }}$ m. ${ }^{\mathrm{e}}$ referir la grandeza de las obras de Dios en sus SS. ${ }^{\text {mas }}$ misericordias particularmente las que obraua en el siervo de Dios el $p .{ }^{e}$ gómes Camacho y su S. ta mujer Cathalina ximénes que uiuían en la siudad de Xeres». Al parecer, los secretos de estas misericordias, que mucho tendrán que ver con el gran secreto guardado por la Congregación de la Granada, fueron comunicados por Dios «al p. ${ }^{\mathrm{e}}$ Camacho y a su S. ta muger los cuales están depositados en la inquisiçión de sevilla y algún día se declararán . $^{\mathrm{a}}$ gloria de dios y de sus $\mathrm{S} .{ }^{\text {tos }} \gg .{ }^{41}$

Amó Francisca especialmente a María de Valer a quien el propio Dios le encomendó su formación espiritual. Sin embargo, el orden de sucesión en la prelatura en la persona de María de Valer no fue declarado por la divinidad a la abadesa sino a través de Catalina Jiménez, la mujer de Gómez Camacho. Así en 1564:

estando todas las monjas en el coro en la missa del Padre Benito Ximénes acabada ya la missa una santa que avía asistido a ella volviendo el rostro vido a sus espaldas a la señora Valer y díjole con mucha alegría: A hija mía, y quánto me alegro de hallarla aquí para desirle una mersed que Nuestro Señor le a hecho que es el darle la capa de prelada, la cual goze muchos años. ${ }^{42}$

Tras esto, Catalina Jiménez se dirigió a la abadesa para comunicarle la nueva. Ambas mujeres se regocijaron al tiempo que Francisca recibía una revelación de la intención de Dios de que compartiese con María de Valer todas las mercedes que le fuese concediendo «sin ocultarle ninguna». Pero no lo hizo, por humildad

${ }^{41}$ Libro de la vida y Milagros de nra santa madre Doña fransisca de uera...... Mss del convento de Lebrija, p. 152. En realidad, esta lebrijana Cofradía de las Misericordias, como también es llamada, es un correlato de la sevillana Congregación de la Granada o, más bien, de su jerarquía formada por el cabeza y los seis del particular espíritu. Tenemos noticias de ella correspondiente al año 1607 en el libro de Pedro de Jesús María, p. 67v, en el que se alude a la «Cofradía de las Missericordias que con Bulas de su Santidad auía instituido el P. Gómez Camacho».

${ }^{42} \mathrm{El}$ manuscrito de la biblioteca particular sevillana dice que la visión la tuvo «una santa»; sin embargo, el conservado en el convento lebrijano afirma que la tuvo «la $\mathrm{S} .{ }^{\text {ta }} \mathrm{m} .{ }^{\mathrm{e}}$ Cathalina ximénes mujer del S. to varón Gómez Camacho». 
«y, temerosa de que el ladrón de la vanagloria no le hurtase su tesoro», no compartió con la heredera una merced, de tantas concedidas por la divinidad, por lo que ésta volvió a recordarle a Francisca la obligación de compartir la merced con Valer, algo que nuevamente iba a dejar de realizar; sin embargo, Dios iba a recurrir a un truco, hizo perder la llave del sagrario por lo que la abadesa desesperaba, así en su interior oyó decir: «en tanto que no abrieres la boca para comunicar la merced que te hise con María de Valer, no pareserá la llave ni se abrirá el sagrario». Francisca narró, además de a su confesor García del Ojo, a María de Valer lo sucedido y, en adelante, no hubo más secretos entre ambas.

Francisca de Vera recibió de Dios revelaciones de todo tipo. En sus treinta años de prelatura conoció diez de ellos sin entrar novicia alguna, fue Dios quien le reveló la entrada de once de ellas; y así fue, a los pocos días llegaron a negociar la entrada en el convento los parientes de nueve doncellas de Lebrija que, en un espacio de tres años, tomaron el hábito. Al poco tiempo, y debatiéndose sobre la imposibilidad de que de Lebrija entrasen otras dos para cumplir el número prometido, llegaron «dos doncellas de la ciudad de Xerez de la Frontera».

Tuvo otras visiones sobre el levantamiento en diciembre de 1568 de los moriscos en Granada. Ocurrió una noche muy cerca de la navidad mientras oraba en el coro. Pasó toda la noche llorando y gimiendo y una monja le oyó decir: «cómo bien mío en noche de tan grande regocijo y favor, cómo hisistir a los hombres, en nacer por ellos, permitís que suceda tal cosa». A los pocos días, en la víspera de la pascua de navidad, llegó la noticia del levantamiento de los moriscos en Granada «y en esta guerra murieron tantos como se sabe». La monja narró lo que había oído decir en el coro a Francisca de manera que todos comprendieron el verdadero espíritu de la abadesa «y que fue verdadero el espíritu de profesía y de que Dios la avía dotado mostrándole el trabajo en que estava su Yglecia para que por sus ruegos y oraciones aplacase la yra de Dios».

Según su biógrafa Dios la benefició hasta el último momento pues «diole una grave y penosísima enfermedad de que murió». Fue el premio a tan excepcional vida, aunque Dios le permitió elegir si quería o no morirse en ese momento, si bien ella delegó en la divinidad su elección. Murió el 21 de diciembre de 1574 a los sesenta años de edad y treinta de prelatura como abadesa del convento.

Cuando murió su sucesora María de Valer, Francisca de Vera fue desenterrada y sus huesos se dispersaron a modo de reliquias por cuya mediación se realizarían muchos milagros. Una de esas reliquias fue a parar a uno de los protagonistas de nuestra historia: el platero sevillano, vecino de la alcaicería, Juan del Salto, discípulo de Rodrigo Álvarez quien, con toda seguridad, le proporcionó la citada reliquia y que, por su mediación, curó a Damiana, su hija de cinco de años de edad desahuciada de los médicos. Más tarde Juan del Salto 
agradecido llevó a esta y otra hija al convento lebrijano en el que llegaron a ser piadosas monjas. ${ }^{43}$

\section{Rodrigo Álvarez, CABEZA DE LA CONGREGACIÓN DE LA GranADA}

Buena parte de lo que sabemos de esta Congregación está ya editado por Domínguez Ortiz y Álvaro Huerga, que siguen en su discurso el memorial elevado a la Inquisición por Mateo Vázquez de Leca y Bernardo de Toro y el informe del calificador dominico, Domingo Farfán, elaborado en $1626 .{ }^{44}$ Por ahora, y en cuanto a lo que a nosotros nos interesa en este trabajo, se puede concluir, con Huerga, que Gómez Camacho fue el fundador de una dinastía espiritual, de un árbol genealógico místico que perdura hasta Bernardo de Toro, el último de los cabezas de la Congregación conocido ${ }^{45}$ En esencia se trata de una congregación

\footnotetext{
${ }^{43}$ «por ella hizo Su Magestad otro rarísimo milagro y fue que uno de estos dichos devotos que se llamava Joan del Salto tenía grandísima fe con nuestra santa madre y sucedió que a una hija suya de edad de cinco años le dio una grauísima enfermedad de dolor de costado tan recio que luego se entendió moriría y sus padres por ser la niña mui linda afligieronse mucho y procuraron la curaran los mejores doctores que avía en Sevilla, mas viendo que nada aprouechava y la enfermita se moría acordóse su padre de la santa reliquia que tenían y con grande fee se lo puso a la niña y en ese punto mejoró y se leuantó y un día dejáronse la santa reliquia en la cama y dióle a la niña una calentura terrible, su madre contristadíssima de ver la recaída en su hija que la amaua terníssimamente y avisando al dicho Joan del Salto su padre el cual viéndola tan malita preguntó que si tenía puesta la santa reliquia y hallaron que no la traía consigo pusieronsela y al punto sanó la niña y esto sucedió por tres veces que así que se les olvidava de ponérsela volvía a recaer, quiso Nuestro Señor fuera manifiesto a todos que por aquella santa reliquia concedía Su Magestad salud a aquella criatura y como esta santa fue tan parecida a su esposo fuelo en esto que a todos los que sanava en el cuerpo cuidava también de la salud de sus almas, y así lo hizo con esta llamaváse Damiana y sus padres por las noticias que tenían de este conuento y su mucha perfección siendo la niña de seis a siete años con otra ermanita suya que oy vive las traxo a esta villa y las entró monjas en este conuento donde vivió esta niña como si fuera ángel en su naturaleza pues jamás se le conoció en toda su vida (roto) de mansedumbre (roto). Dotóla Nuestro Señor de muchos dones de virtudes que esclaresían en ella y en particular el del çilencio y oraçión en la cual gastava tres oras de una ves de rodillas sin mouerse que parecía era aquel cuerpo de piedra según estava de inmobile, estando su espíritu todo en el cielo y lleno de Dios por cuyo amor padeció mucha mortificación y vida mui penitente y siendo de poca edad aviendo vivido debajo de los estatutos de su Regla la cual cumplió perfetissimamente, le dio Nuestro Señor una enfermedad mui larga que fue de ética la cual sufrió con mucha pasiencia y conformidad con la divina voluntad y a fin de un año de padeserla llevó su regalado esposo dejando muestras y grandes prendas de su salvación pues a la ora de su gloriosso tránsito se oyeron voces del cielo que con suave melodía llevavan aquel alma a gozar de los premios de tan linda vida. Oy en día que se escribe esto viven las monjas que las oyeron y dicen no an oído jamás música tan suave al oído y de tanto consuelo como aquella». Biblioteca particular de Sevilla. Códice de la Granada s/f. Vida y Milagros...

${ }^{44}$ Domínguez Ortiz, A. 1983: 161-177; Huerga, A. 1988: 217-237. Bernardo de Toro. Memorial sobre la vida de Gómez Camacho. A.H.N. Inquisición, leg. 2957/2. Domingo Farfán, Informe calificador sobre la Congregación de la Granada. A.H.N. Inquisición, leg. 2963/1.

${ }^{45}$ Huerga, A. 1988: 37. Aunque hay que tener en cuenta que tras la marcha de Toro a Roma quedó, en una especie de tenientía, como cabeza de la Congregación Francisco del Castillo, «clérigo presbítero
} 
religiosa, hasta cierto punto hermética, regida espiritualmente por un cabeza y que, según Toro, fue fundada por Gómez Camacho, bajo la influencia espiritual de la monja mínima Marta de San Andrés, al que siguió Rodrigo Álvarez, a éste le sucederá Hernando de Mata y, por fin, Bernardo de Toro que es el último $c a$ beza de la Congregación conocido.

Tenían establecido una sucesión de esta prelatura hasta el fin del mundo; además, aparte del cabeza de la Congregación, existían los denominados seis del particular espíritu que compartían con el cabeza un singularísimo secreto que se había ido transmitiendo de unos a otros; por último, se hallaban otros miembros comunes que no tenían conocimiento del secreto pero que actuaban en las prácticas de la Congregación.

En puridad no puede llamársele Congregación de la Granada desde la fundación del conventículo de Camacho en Jerez-Lebrija hacia 1546, sería más lógico que fuese así conocida desde la prelatura de Hernando de Mata, nombrado en 1580 por el cabildo catedral para predicar en el púlpito de la Granada, en el patio de los naranjos de la catedral sevillana, célebre por los predicadores que por él pasaron y que es, el púlpito, el que verdaderamente da nombre o, al menos, origen a la Congregación y no la capilla de la Virgen de la Granada como prácticamente todos los autores han creído. ${ }^{46}$ En la capilla de la Granada hubo una hermandad, la de Nuestra Señora de la Granada, pero no tiene nada que ver con la Congregación de la Granada, que toma su nombre de las reuniones que Mata realizaba allí con sus congregados. Hernando de Mata se hizo famoso en Sevilla por sus sermones en el Sagrario predicados los domingos entre siete y ocho de la mañana. Es más, si atendemos a su biógrafo debemos concluir que fue Mata quien fundó y organizó esta Congregación: «Persiguieronle algunas personas principalmente eclesiásticas, calumniando sus acciones, y la asistencia a la Academia o Congregación que para la instrucción y aumento en las virtudes formó». ${ }^{47}$ Aunque esto no constituía un impedimento para que Hernando de

y confesor» que fue castigado por la Inquisición en el auto público de fe de 1624. Vid. Huerga, A. 1988: 492. Sin embargo, también se conoce que delegó en Álvaro Bello y en una Junta de cuatro clérigos. Vid. Huerga, A. 1988: 229. En realidad, y como ya hemos comprobado, Rodrigo Álvarez no funda nada, simplemente es continuador, eso sí en Sevilla, de una escuela espiritual que tiene su origen en su propio pueblo, Lebrija, y en la Jerez de Gómez Camacho y Marta de San Andrés.

${ }^{46}$ El posible error parte de Domingo Farfán quien en su informe afirma: «se llama con este nombre por estar situada en la capilla de Nuestra Señora de la Granada, en la iglesia mayor de Sevilla». Vid. Huerga, A. 1988: 488. Véase la historia de esta hermandad en Archivo General del Arzobispado de Sevilla. Hermandad de la Granada, leg. 1, exp. 1/1-9.: Exp. 7. Protocolo de Nuestra Señora de la Granada (en realidad en este libro se narra la historia del púlpito, la nave y la capilla de la Granada). De cualquier forma, parece que a partir de la marcha de Bernardo de Toro a Roma, la Junta de la Congregación compuesta por cuatro clérigos (el canónigo Diego Herber de Medrano, Francisco del Castillo, Álvaro Bello y Francisco Milanés) se reunían en esa capilla y es posible que desde el informe de Farfán se denomine así por ese motivo. Vid. Huerga, A. 1988: 366.

${ }^{47}$ Jesús María, P. de. 1669: 45r.

Hispania Sacra, LXIV

129, enero-junio 2012, 141-186, ISSN: 0018-215-X, doi: 10.3989/hs.2012.005 
Mata se sintiera un eslabón genealógico de un grupo espiritual surgido ochenta años antes en Jerez-Lebrija de cuyo patrimonio espiritual era el principal heredero.

Tal vez esta Congregación hermética, del púlpito que está junto a la Capilla de la Granada, no hubiera sufrido ningún tipo de persecución de la Inquisición si no se hubiese decretado la investigación de los alumbrados a partir de 1622 $\mathrm{y}$, sobre todo, si no se hubiese verificado el impulso del inmaculismo surgido en Sevilla en 1613-18 con la consiguiente enemiga de los dominicos. Estos, humillados por los sevillanos, ante su oposición al dogma y, muerto el arzobispo Castro, pasaron al ataque: «La ofensiva desarboló y dejó en jarcias a la Congregación de la Granada». ${ }^{48}$ En esta campaña sevillana por la definición del dogma inmaculista, que arranca en 1615, la Congregación de la Granada, o más bien su cabeza, el clérigo predicador del púlpito de la Granada, Bernardo de Toro, entronca con las necesidades del arzobispo de Sevilla, Don Pedro Vaca de Castro y Quiñones, de conseguir la definición del dogma inmaculista, del que era extraordinariamente devoto.

Tal unión de voluntades no hubiera podido darse si el origen genealógico de la Congregación, Gómez Camacho, no hubiera profetizado, tal como vimos, en 1549 el dogma, con seguridad al hilo de lo leído en el libro de Amadeo de Silva (c. 1431-1479) Apocalipsis Nova en el que se recogen las revelaciones que el arcángel Gabriel hizo al beato Amadeo, un beato cuyas profecías estaban, en buena medida, en la línea de las de Joaquín de Fiore y de Francisco de Paula. Allí se profetiza una decadencia de la Iglesia y la venida de un Papa Angélico así como el propio dogma de la Inmaculada en la línea marcada por el franciscanismo y sobre todo por Duns Scoto. ${ }^{49}$ No es casualidad que Don Pedro de Castro poseyera un ejemplar manuscrito del Apocalipsis Nova ¿Tal vez creyó que él sería el Papa que llegaría a definir el dogma? ${ }^{50}$

\footnotetext{
${ }^{48}$ Huerga, A. 1992. Los dominicos en Andalucía. Sevilla: 174 Sevilla.

${ }^{49}$ Ya Domínguez Ortiz había advertido esta relación: «Desde luego, hay un nexo indudable entre la Congregación de la Granada y el misterio de la Inmaculada». Domínguez Ortiz, A. 1983: 166. Además, entre las creencias de los congregados estaba la siguiente: «tienen los de esta Congregación por particular y cierta observancia y como profecía que, en definiéndose por de fe el punto de la Concepción de Nuestra Señora, habían de reformar la Iglesia los congregados de la dicha Congregación». Vid. Huerga, A. 1992: 221. La información proviene del informe del calificador dominico fray Domingo Farfán, A.H.N. Inquisición, leg. 2963/1.

${ }^{50}$ Calero Palacios, M. C. 1999. La abadía del Sacromonte de Granada: catálogo de manuscritos: 123 Granada. La copia del Apocalipsis Nova del Sacromonte, donde fueron a parar los libros de don Pedro de Castro, tiene fecha de 1543, y está relacionada con San Pedro de Alcántara pues en el colofón dice: «Io fray Pedro de Alcántara de la Orden de San Francisco de la provincia de San Gabriel doi testimonio en como vi trasladar el libro suprascripto del beato Amadeo a fray Antonio Ortiz de otro libro que traxo prestado de la provincia de los Angeles». Ni que decir tiene que Don Pedro era muy capaz de pensar eso, ya en los libros plúmbeos aparece el arzobispo como objeto de una conversación entre la Virgen y San Pedro en donde se le auguraba una recompensa especial en la gloria eterna. También los cabezas de la Congregación de la Granada debieron tener este Apocalipsis o, al menos, impresos rela-
} 


\section{LA PERSONALIDAD DE RodRIGo ÁlVAREZ (S.I.)}

Tres fuentes fundamentales guardan la memoria de este cabeza de la Congregación de la Granada y confesor de Teresa de Ávila: la recogida en la historia de la provincia de Andalucía de la Compañía de Jesús, escrita por Martín de Roa. La segunda, se guarda en la sección Bética del Archivo Romano de la Compañía de Jesús, despreciada por Huerga. Se basa en la información proporcionada por un discípulo de Álvarez, que era uno de los de particular espíritu de la Congregación. Se trata del platero Juan del Salto, al que ya hemos visto curar a su hija por medio de una reliquia de Francisca de Vera y entregar a dos de sus propias hijas para profesar en el convento lebrijano. Envió éste su relato al jesuita Pedro Suárez quien redactó diez cuartillas fechadas el 7 de diciembre de 1610. La tercera son los elogios que acompañaban a su retrato en el Libro de Verdaderos Retratos de Francisco Pacheco. ${ }^{51}$

Según Roa, Rodrigo Álvarez habría nacido en septiembre de 1523 en una población del norte de África. Algo que va a desmentir Juan del Salto en su información necrológica a los jesuitas, Bernardo de Toro, en su ya célebre memorial, e incluso Pacheco que, a pesar de remitir al lector a Roa, afirma que el jesuita nació en Lebrija. En efecto, así se demostraba por medio de una partida de bautismo que, según Juan del Salto, conservó siempre Hernando de Mata. ${ }^{52}$

Al parecer estudió las primeras letras en Lebrija para cursar más tarde Artes y Teología en la Universidad de Alcalá..$^{53}$ Tras terminar sus estudios volvió a Lebrija en noviembre de 1543 en la que «tuvo allí familiar trato y estrecha co-

tivos a la obra de Amadeo, pues el 2 de septiembre de 1623 el presbítero Francisco Milanés, uno de los cuatro miembros de la Junta de la Congregación de la Granada que Toro dejó en Sevilla a su marcha a Roma, entregaba en la Inquisición sevillana un escrito pidiendo la devolución de documentos del «Arca de Papeles y Archivo de la causa de la Santa Concepción de Nuestra Señora» que custodiaba el citado presbítero por orden, según él, del Arzobispo de Sevilla Don Pedro de Castro, entre esos papeles se encontraba: «Otro volumen de papeles impresos del Beato Amadeo». A.H.N., Inquisición, Leg. 2960. De cualquier forma las profecías amadeistas están en relación con las de Joaquin de Fiore y la que ya conocemos de Francisco de Paula.

${ }^{51}$ Roa, M. de. 2005. Historia de la Provincia de Andalucía de la Compañía de Jesús (1553-1662). Edición de A. Martín e I. Carrasco: Écija. Las declaraciones de Juan del Salto en Archivum Romanum Societatis Iesu. ARSI. Baetica 25, Necrología I (1570-1648), ff. 19r-37v. Pacheco, F. 1985. Libro de descripción de verdaderos retratos e ilustres y memorables varones. Edición de P. M. Piñero y R. Reyes. Sevilla: 377-382 Sevilla. En el ARSI. Cartas Triennales 1583, 1585, fols. 2 y 18, aparece como patria Lebrija. Al parecer Juan del Salto fue requerido por parte de la Compañía de Jesús para atestiguar sobre la vida de Rodrigo Álvarez, del que era discípulo espiritual. La Compañía pensaba incluirlas en la Historia General de la misma que se estaba realizando. Juan del Salto se prestó a ello: «Y assí obedeciendo a lo que se me a mandado, certifico con toda asseveración, que todo lo que aquí dixere será toda verdad, porque no pretendo más que la mayor gloria de Dios y la onrra de aquel santo varón, y affirmo que hablo de lo que oý, y testifico lo que ví», fol. 19r.

${ }^{52}$ ARSI. Baetica 25, Necrología I (1570-1648), fol. 33v.

${ }^{53}$ En efecto en las Cartas Triennales aparece con esos estudios. ARSI. Cartas Triennales. 1583, 1585, fols. 2 y 18. En la de 1585 aparece con el grado de Bachiller en Teología.

Hispania Sacra, LXIV

129, enero-junio 2012, 141-186, ISSN: 0018-215-X, doi: 10.3989/hs.2012.005 
municación con Gómez Camacho, hombre seglar y casado, de rara virtud y muy ilustrado del cielo, a quien el Padre llamaba su Padre Espiritual, por lo mucho que había sido ayudado en espíritu de sus consejos». ${ }^{54}$ Según Roa fue un hombre de posibles hasta que se deshizo de ellos repartiéndolo entre los pobres de su villa, por lo que para subsistir puso una escuela de Gramática. ${ }^{55}$

No cree Juan del Salto que, para subsistir como dice Roa, pusiera «estudio de latinidad en Lebrixa», sino para «ganar las almas de la juventud para Dios y encaminarlas al cielo que es lo que ahora haze la Santa Compañía de Jesús». Según Salto, antes de desposeerse de todos sus bienes, Álvarez puso con el fin declarado su estudio de latinidad, por lo que propone: «advertir y emendar en los primeros quadernos del Padre [Roa] que bien sé yo quien le ynformó le auían ynformado mal y creyose de ligero el que le ynformó». ${ }^{56}$

La información que el jesuita Pedro Suárez envía a Roma, tiene su origen en la falta de credibilidad por parte de la Compañía de la historia de Roa en cuanto a los hechos sobrenaturales ocurridos a Rodrigo Álvarez: «En cumplimiento de lo que V.R. me mandó que hiziesse para responder a la cédula que an remitido de Roma en que se duda de la autoridad de las cosas milagrosas, que están escritas en la Historia de esta Provincia del Padre Rodrigo Álvarez de santa memoria, digo lo siguiente después de aver hecho la diligencia que e podido». ${ }^{57}$ Entre las cosas que decía Suárez destaca la absoluta credibilidad de esas «cosas milagrosas», no había que poner en duda nada pues Rodrigo Álvarez «desabrochó su pecho», aludiendo a la santa obediencia que debía al provincial Diego de Acosta, a otros padres doctos de la compañía, para lo cual el provincial hubo de anular a Álvarez un voto realizado «de no comunicar sus cosas a criatura ninguna». Aparte de ello, tras su muerte, se encontraron muchos otros casos sobrenaturales escritos de su propia mano, papeles que estaban en poder «de un gran siervo de Dios, sacerdote, que está en esta ciudad y se llama el licenciado Fernando de Mata, que el qual fue gran hijo del padre Rodrigo Álvarez, y oy tiene escuela de espíritu, adonde acuden muchas personas assí seglares como ecclesiásticas con mucho provecho de sus almas».58

En el momento de esta declaración existían tres discípulos vivos de Rodrigo Álvarez, uno de ellos era el declarante, Juan del Salto «ombre casado, y es platero de oro y ombre mui virtuoso, y de mucha verdad y crédito, de muy buen

\footnotetext{
${ }^{54}$ Roa, M. de. 2005: 283 [fol. 193v].

${ }^{55}$ La abadesa del convento lebrijano, Francisca de Vera, encargó a una de sus hermanas en las pláticas de las misericordias realizadas por la divinidad a Gómez Camacho, la madre Luisa de la Cruz «que le guisara la comida al $\mathrm{p} .{ }^{\mathrm{e}}$ Rodrigo aluares qu. ${ }^{\text {do }}$ estuvo aquí con escuela de gramática. S. ${ }^{\text {to }}$ varón y . $^{\mathrm{e}}$ de la compañía de gesús». Libro de la vida y Milagros de nra santa madre Doña fransisca de uera...., Mss del convento de Lebrija, p. 181.

${ }^{56}$ ARSI. Baetica 25, Necrología I (1570-1648), fol. 34r.

${ }^{57}$ Ibídem, fol. 34v.

${ }^{58}$ Ibídem, fol. $35 \mathrm{r}$.
} 
nombre en esta Ciudad, confiessa y comulga a menudo, es penitente al presente del Padre Gaspar de Çamora el qual dize en abono del dicho Juan del Salto, que firmará de su nombre sin más averiguación qualquier cosa que dixere». ${ }^{59}$

Encontrándose en esta situación, persuadió a Rodrigo Álvarez «alguna gente devota que se ordenase sacerdote». Así lo decidió, aunque para ello hubo de ser dispensado pues era irregular ya que «tenía el ojo izquierdo seco i el derecho con una nuve».$^{60}$ En noviembre de 1552, ordenado de presbítero, pudo entrar como capellán del convento de la Purísima Concepción de Lebrija, en el que asistió a la conversión de la hermana de Francisca de Vera, tal como explicita el manuscrito lebrijano que afirma claramente que Álvarez era hijo espiritual de Gómez Camacho: «venida la mañana el S. ${ }^{\mathrm{r}}$ gómes Camacho estando con el p. ${ }^{\mathrm{e}}$ R. ${ }^{\circ}$ alvares de la compp. ${ }^{a}$ de Jesús, cuia s. ${ }^{\text {ta }}$ vida está en su religión escrita, hijo espiritual del S. ${ }^{\text {to }}$ Gómez Camacho $[\ldots] \gg .{ }^{61}$

En el convento de Lebrija vemos a Rodrigo Álvarez asistir como confesor a la hora de la muerte de dos monjas fundadoras: Antonia de San Francisco ${ }^{62}$ e Isabel Vidal. ${ }^{63}$ Conectó con el grupo de espiritualidad recogida que allí se formó. Tras esto, el eje espiritual Jerez-Lebrija está a punto de convertirse en triángulo: Jerez-Lebrija-Sevilla, pues Rodrigo Ảlvarez parece que acudió a socorrer espiritualmente a los pobres del Hospital del Amor de Dios y, muy pronto, entró en la Compañía de Jesús, por una revelación del mismo Cristo y la Virgen ocurrida en Jerez, ciudad en la que se hallaba Camacho, por lo que no es de extrañar que

${ }^{59}$ Idem.

${ }^{60}$ Pacheco, F. 1985: 379. Lo ordenó, también bajo aspectos pseudomilagrosos, el provisor Don Juan Fernández Tremiño quien en 1546 sería elegido obispo de León.

${ }^{61}$ Libro de la vida y Milagros de nra santa madre Doña fransisca de uera....; Mss, del convento de Lebrija, p. 33.

${ }^{62}$ «Dióle la última enfermedad de que murió, entróla a confesar el Padre Rodrigo Álvares, que después fue padre de la Compañía, varón de gran virtud el cual en esta ocasión hiso una plática del voto de la pobresa, la obligación que tenemos las religiosas de guardarla y que fuera con tal perfección que en rompiéndose un remiendo avían de echar otro y otro que no avían de remendar una sola ves ni contentarse sino con más y más pobresa a imitación de esta santa que siempre fue amiga de seguir lo mejor y toda perfección religiosa por lo qual meresió el premio que oy gosa que es el ver a Dios. Según se debe creer por el informe de su santa uida y dicho de su confesor la gran puresa de alma que en esta santa conosió». Biblioteca particular de Sevilla. Códice de la Granada s/f, Memorial de la fundación de este conuento de Nra. Sra. de la Ynmaculada Consepción de la villa de Lebrixa y Traslado de las vidas de las fundadoras y de nuestra santa madre y Abbadesa Doña Francisca de Vera, segunda Abbadessa que uvo en este dicho conuento.

${ }^{63}$ «le quiso el Señor premiar llevándola para sí a gosar de los premios de sus santas obras muriendo como vivió dejando embidiosas a todas las que se hallaron en su santa muerte y glorioso trançito, al cual se halló presente el Padre Rodrigo Álvarez antes que se hisiera Padre de la Compañía de Jesús, siendo saçerdote y su confesor que entró a sacramentarla y dijo grandiosas cosas del espíritu de esta santa que por la antigüedad no los tienen todos escritos». Idem. Pedro de Jesús María lo afirma: «fue dicipulo del dicho Padre Gómez Camacho, con ser casado, y por su consejo, y mandato entró y murió en la dicha Compañía de Jesús». Jesús María, P. de. 1669: 4v.

Hispania Sacra, LXIV

129, enero-junio 2012, 141-186, ISSN: 0018-215-X, doi: 10.3989/hs.2012.005 
fuera el famoso cerrajero profeta quien lo incitara a ingresar en la Compañía. ${ }^{64}$ Fue admitido, a pesar de que él mismo relató al provincial Diego de Avellaneda sus faltas, evidentes, pues «vieron un hombre entrado en edad, tuerto de un ojo, mal agestado y de semblante feo y desagradable en la manera del hablar». ${ }^{65} \mathrm{La}$ entrada tuvo lugar el lunes 12 de agosto de 1566. Tenía Rodrigo 43 años.

\section{LA ESCUELA ESPIRITUAL DE RodRIGo ÁlVAREZ y SUS DISCÍPULOS}

Esta escuela o academia espiritual no puede denominarse con el apelativo de Congregación de la Granada. Álvarez no predica en el famoso púlpito y está sometido a la disciplina de la Compañía. Según Juan del Salto, cuando Álvarez llega a la capital andaluza «se le allegaron en Sevilla algunos pocos varones, aunque de todos estados, casados, sacerdotes, continentes, Biudos, Religiosos, ermitaños, y algunas mugeres de mucha virtud, especial después de aver tratado con el Padre y queriendo alguno llevarle más, dixo: no me traigan gente». ${ }^{66}$

La Congregación de la Granada toma ese nombre con Hernando de Mata, que predica en el púlpito que está junto a la Capilla de la Virgen de la Granada, y con Bernardo de Toro que también predica allí, ambos por nombramiento catedralicio. Se trata de una escuela o academia parecida al grupo de Gómez Camacho o a la reunión selecta de Francisca de Vera con algunas de sus monjas: la Congregación de las Santísimas Misericordias. Es una escuela de espíritu cuyo maestro principal es Rodrigo Álvarez (1553-1587), que había bebido en las fuentes espirituales de Camacho y Vera. Sucedió a Álvarez Hernando de Mata (1587-1612), su discípulo predilecto y, más tarde, Bernardo de Toro (1612-1643) que lo fue de Mata. ${ }^{67}$

Se basaba, en primer lugar, en la dirección de conciencia y la confesión, pues en la sociedad de la sacralización, del escrúpulo, de la trascendencia, del dominio de la razón trascendente, muchas personas pretendían encontrar algún director de su propia vida, de su intimidad. El proceso de acceso a esa escuela nos lo da a conocer el platero Salto:

uvo uno, que biviendo muy tentado, affligido, i deconsolado en muchos años buscando de propósito algún santo religioso, que le entendiesse, y diesse remedio, jamás lo halló, hasta que encontró con el Padre Rodrigo Alvarez: entonces reposó y no buscó más, porque conoció que le entendió su camino, y enfermedad, porque sin él saberse manifestar ni declarar, sino callando, el Padre le respondía a las dudas de su coraçón, y le dezía, haga esta devoción, y esta, y reze esto y esto. ${ }^{68}$

\footnotetext{
${ }^{64}$ Roa, M. de. 2005: 284 [194v].

${ }^{65}$ Ibídem, p. 285 [195r].

${ }^{66}$ ARSI. Baetica 25, Necrología I (1570-1648), fol. 19r.

${ }^{67}$ Las fechas son de la prelatura como cabezas de la Congregación de la Granada.

${ }^{68}$ ARSI. Baetica 25, Necrología I (1570-1648), fol. 19r.
} 
En otras ocasiones era el propio Álvarez quien enrolaba en su escuela al discípulo: «uno de los que se llegaron al Padre estándolo hablando le dixo: Dios a de hazer grandes misericordias, si me queréis seguir, y sintió el dicho ombre una estimación y aprecio de aquello, que el Padre le dixo, y un mover su voluntad a acetar el seguirle, y interiormente diziendo: y en qué cosa puedo yo seguir a tal Padre que no me venga a mí del cielo el seguirle». ${ }^{69}$

Juan del Salto se refiere a sus condiscípulos como «los allegados», «discípulos» «íntimos amigos», «los continuos», «de los que tratavan», «de los que comunicaban» con Rodrigo Álvarez. En su relato dará un pequeño listado de algunos de ellos. Así cuando el jesuita Pedro Suárez, encargado de comprobar la veracidad de los hechos sobrenaturales que Roa había escrito sobre Álvarez, le dio a leer esto a Juan del Salto para pedir su opinión general, este le contestó:

Lo que del Padre está escrito con ser tan grave, es no más, de como si un costal de perlas, o margaritas preciosas sacassen media dozena, y las comunicassen y diessen dexandose lleno el costal. Mucho dello dexó el Padre escrito por obediencia como se dize en la Historia y de las cosas que se dizen del Padre Rodrigo Álvarez fue testigo el Padre Diego de Acosta, Provincial, también fueron testigos el Padre Ioseph de Cuadros, y el Padre Gerónimo de Çaragoça (ambos de la Compañía de Jesús) y el dotor Bartholomé García del Ojo, visitador que fue de monjas en este arçobispado de Sevilla, y Francisco de Castro Çurujano (este fue gran santo y conocido por tal en Sevilla) y Vasco Perira (sic) pintor (este bivió con grande exemplo) y Juan Baptista Vasques escultor, ombre de buena vida, y Juan Rodriguez Mançera, y el Padre Martín Ruiz, clérigo exemplar, y el Padre Alonso de Villafañe, racionero que fue de esta Santa Iglesia de Sevilla. Todos los quales son ya difuntos. Y más son testigos que ahora biven, el licenciado Fernando de Mata y Pedro de Mesa, bordador. También es testigo el Padre Lope del Castillo de la Compañía de Jesús. ${ }^{70}$

\footnotetext{
${ }^{69}$ Ibídem, fol. $19 \mathrm{v}$.

${ }^{70}$ Ibídem, fol. 35v. No cabe duda de que Juan del Salto nos da aquí los nombres de discípulos de Rodrigo Álvarez o, al menos, compañeros de su grupo espiritual afectos a su especial espiritualidad: Diego de Acosta S. I. (Medina del Campo, 1534-Ciudad Real, 1585); José de Cuadros S. I. (Sevilla, 1565-Málaga, 1609); Jerónimo de Zaragoza S. I. (Córdoba, 1542-Sevilla, 1600) «tras su muerte, el despojo de sus vestidos lo arrancaban a porfía»; Lope del Castillo S. I. (Toledo, 1534-Trigueros 1623); Bartolomé García del Ojo, era de Lebrija y visitador de monjas así como confesor del convento concepcionista de Lebrija, discípulo de Francisca de Vera y de su grupo espiritual; Vasco Pereira (Évora, 1535-Sevilla, c.1609), pintor afamado; Juan Bautista Vázquez (Salamanca, 1510-Llerena, 1588), escultor afamado; Juan Rodríguez Mancera; Martín Ruiz, clérigo; Alonso de Villafañe, racionero catedralicio sevillano († 1603); Fernando de Mata, clérigo (Sevilla, 1554-Sevilla, 1612), sucesor de Álvarez en su escuela espiritual; Pedro de Mesa, bordador natural de Sanlúcar la mayor; Francisco de Castro (i-Sevilla, 1601), cirujano, personaje muy singular y gran amigo de los jesuitas sevillanos, a quien dedica Juan de Santibáñez algunas páginas en su Historia de la Compañía de Jesús en la provincia de Andalucía. Fue admirado en Sevilla en la que, en efecto, era conocido por un santo: «Ni sabían comúnmente llamarlo sino con el nombre de sancto, 'el sancto Françisco de Castro'». Luchó, a su modo, contra los pecados públicos y fundó una casa de recogidas para prostitutas que aprobó Gregorio XIII por una Bula de 11 de julio de 1587, cuyas reglas fueron aprobadas por el arzobispo don Rodrigo de Castro y conservadas, por entonces, en la librería de la Casa Profesa de Sevilla. Tuvo una especial predilección por los jesuitas, «era Françisco de Castro inseparable compañero de los de la Compañía», durante más de cuarenta años les asistió en su oficio, «como barbero o çirujano», sin cobrarles nada. Murió en opinión de santo, en su
}

Hispania Sacra, LXIV

129, enero-junio 2012, 141-186, ISSN: 0018-215-X, doi: 10.3989/hs.2012.005 
La noticia más excepcional es la pertenencia al grupo espiritual de Rodrigo Álvarez de otro artista, uno de los grandes escultores de la escuela sevillana: Juan Bautista Vázquez, «ombre de buena vida». Sabíamos que el pintor de origen portugués y afincado en Sevilla, Vasco Pereira, tal como aquí se dice, era miembro de ese grupo, también conocíamos la adscripción del escultor Juan Martínez Montañés, bajo la prelatura de Hernando de Mata y Bernardo de Toro, ahora conocemos la de otro escultor. ${ }^{71}$

El ambiente social de este conventículo, escuela, academia o congregación, es un mundo de oficiales de la administración, artesanos, artistas, clérigos y monjas inmersos en un universo sacral, mágico en el que los dogmas y, sobre todo, la rígida moral impuesta por la Contrarreforma empujaba a estos hombres y mujeres a ir más allá de la dimensión empírica. Canalizaban su necesaria y vital inmanencia ontológica por medio de una vivencia real de lo que no puede serlo. Llegaron a ser capaces de vivir en un mundo fuera del tiempo, de vivir sus propias «aventuras» irreales en el mundo real, tal como hacía don Quijote. Solo así, en el caso de los artistas, es posible comprender cómo pudieron llegar a realizar las excepcionales obras que nos han legado.

Cuando Juan del Salto realiza sus declaraciones a los jesuitas, amplía noticias dadas ya por Roa. Algunas proporcionan nombres a los protagonistas de esas narraciones. Álvarez soluciona un problema de acreedores a un penitente suyo de una forma milagrosa. Roa no dice de quien se trata. Salto nos informa que fue Juan Rodríguez Mancera. ${ }^{72}$ Asimismo, Roa narra cómo un hombre «en un grande trabajo» acudió a Rodrigo en busca de ayuda, este le dijo: «vaya a la Madre de Dios y pídale de mi parte que se lo quite». El discípulo así lo hizo y, puesto delante de la imagen de la Virgen, quedó libre de lo que le afligía. En la Historia de la provincia no se dice quién era este devoto, ahora Salto dirá: «fue este ombre Vasco Perea (sic), pintor, y compañero individuo suyo hasta que murió». ${ }^{73}$

entierro se oyeron voces como «Vamos a enterrar a el sancto que él rogará por nosotros». Juan de Santibáñez: Historia de la Compañía de Jesús en la Provincia de Andalucía. Mss. C. B 48-50, Biblioteca de la Universidad de Granada. Primera parte, Lib. 2º ff. 233v-236v.

${ }^{71}$ Creemos que debe tratarse de Juan Bautista Vázquez «el Viejo» (c.1510-1588) a quien el discípulo de Francisca de Vera y visitador de monjas del arzobispado, el bachiller Bartolomé García del Ojo, que también cita aquí Juan del Salto como testigo de las «cosas que se dizen del Padre Rodrigo Álvarez», encargó el 1 de diciembre de 1577 el retablo de la Virgen de la Piña de la Parroquia de Santa María de la Oliva de Lebrija, vid. Palomero Páramo, J. M. 1986. «Juan Bautista Vázquez el Viejo y el retablo de la Virgen de la Piña, de Lebrija», Archivo Hispalense, 210: 162. Por otro lado, la espiritualidad de Vasco Pereira va en consonancia con la excepcional biblioteca religiosa que poseía, vid. Fernández López, J. 2002. Programas iconográficos de la pintura barroca sevillana del siglo XVII: 43-53 Sevilla: Universidad de Sevilla. Nuestro informante, el platero Juan del Salto, fue albacea testamentario del escultor Andrés de Ocampo. Vid. Bago Quintanilla, M. 1930. «Aportaciones Documentales», Documentos para la Historia del Arte en Andalucía: II, 38. Sevilla.

${ }^{72}$ Roa, M. de. 2005: 289 [198v-199r.]; ARSI. Baetica 25, Necrología I (1570-1648), fol. 35v.

${ }^{73}$ Ibídem, fol. 35v. 
Salto también nos ilustra sobre la actividad caritativa de Álvarez y sus discípulos. Un buen día acudían estos al hospital a visitar a los pobres. Álvarez, que tuvo que quedarse en la Casa por orden de su superior, «dijo él a sus discípulos que fuesen ellos a consolar los enfermos en su nombre». ${ }^{74}$ Estos hallaron a un pobre tullido afligido por la enfermedad y por el desamparo de su mujer e hijos que no tenían de qué alimentarse, lo animaron «con las palabras y razones de su maestro», en lo que es un cumplimiento exacto de su enseñanza, a la mañana siguiente el tullido estaba curado. Del Salto nos aclara que no fueron los discípulos los que suplieron al maestro, sino solo uno de ellos: «Le pasó al dicho Vasco Pereira, a quien el Padre Rodrigo Álvarez embió al ospital a visitar los enfermos en su nombre». ${ }^{75}$

Narra también Roa el caso de un estudiante, que llegó a Rodrigo «grandemente perseguido y combatido de tentaciones y espíritu de desconfianza». Rodrigo lo confortó y, apenas habían rezado un Ave María, la alegría y felicidad se apoderaron del corazón del estudiante. Del Salto nos dice que era Alonso de Villafañe, quien más tarde sería racionero de la catedral sevillana.

\section{Rodrigo Álvarez y su Relación con SANTA Teresa de Jesús}

Si en algo destacó Rodrigo Álvarez fue en el discernimiento de los espíritus. El jesuita se reveló como un experto confesor de personas espirituales. Tuvo una gran capacidad de lucha contra los espíritus malignos que atormentaban a un gran número de estas personas que se creían videntes o espirituales y, en realidad, estaban dominadas por el demonio, por lo que, como fruto de esa cualidad, llegó a escribir una especie de tratado sobre confesión de espirituales engañados por el demonio. ${ }^{76}$ Debido a esa especial cualidad fue, durante su estancia en Sevilla, confesor de Santa Teresa, es decir, calificador inquisitorial de su espíritu, una relación que es posible seguir, en parte, por las cartas de la propia santa y en la que Teresa bien pudo ser advertida por Álvarez sobre la famosa profecía acerca de los Crucíferos de Francisco de Paula.

Como es de sobra conocido Teresa de Ávila con sus descalzas arribó a Sevilla, sin ella desearlo y cumpliendo una orden de su prelado Gracián de la Madre de Dios, el 26 de mayo de 1575. Poco tiempo después, a primeros de octubre, recibió en su convento como novicia a una beata «que estaba ya canonizada por toda la ciudad y por la importunidad de mucha gente principal se recibió». ${ }^{77} \mathrm{Se}$ trataba de María del Corro, una viuda y beata que no se adaptará, según María

\footnotetext{
${ }^{74}$ Roa, M. de. 2005: 289 [199v].

${ }^{75}$ ARSI. Baetica 25, Necrología I (1570-1648), fol. 36r.

${ }^{76} \mathrm{Se}$ trata de la Suma de los solícitos engaños que el demonio hace en estos miserables tiempos. Huerga, A. 1988:106-111.

${ }^{77}$ San José, M. de. 1913. Libro de las Recreaciones: recr. IX, 109. Burgos: Monte Carmelo. 
de San José, a la regla descalza y que terminará, al parecer apoyada por un clérigo melancólico, por denunciar a la Inquisición sevillana como alumbradas a Teresa y sus monjas. Como consecuencia de esta denuncia, Teresa fue requerida tanto por el tribunal ordinario diocesano como por el Santo Oficio, al objeto de examinar su vida y su espiritualidad. ${ }^{78}$ Es aquí donde entra en juego Rodrigo Álvarez quien, gracias a su experiencia en el discernimiento de espíritus, fue llamado por la Inquisición de Sevilla, como consultor de la misma, para que examinase el espíritu de la santa de Ávila. Aunque el proceso se ha perdido, han quedado los memoriales -en realidad una extensa confesión general, tan cara a los jesuitas- que la propia Teresa escribió con destino a Álvarez, y que se erigen como un documento fundamental para el conocimiento de la espiritualidad de la santa. ${ }^{79}$ Pero el que debía juzgar, y quizás esto no lo conocía nada más que su círculo o escuela espiritual, era tan espiritual -y, supuestamente, tan alumbradocomo la propia santa, así que ambos llegaron a conectar desde lo espiritual muy satisfactoriamente.

Si bien esto no ocurrió desde el principio. Todos los historiadores de estos hechos aluden a la bondad del jesuita Enrique Enriquez y su intención, desde el primer momento, de ayudar a la santa, para lo que habló en varias ocasiones con Álvarez; pero este se mostraba hostil, gran conocedor de los espíritus, espiritual él mismo, tenía ciertas prevenciones para quien confesaban arrobos e interrelación con la divinidad, algo que fue relativamente común en el ambiente espiritual sevillano y que, en buena medida, gran paradoja, Rodrigo Álvarez había desenmascarado. ${ }^{80} \mathrm{El}$ examen que Álvarez practicó a Teresa fue duro, el propio de un calificador del Santo Oficio que sigue su praxis procedimental, según Enriquez «le hacía escribir por menudo todas las cosas que por ella habían pasado, y ratificarse en ellas, examinándola y repreguntándola». ${ }^{81}$

\footnotetext{
${ }^{78}$ Para todo el desarrollo de este procese Vid. Llamas Martínez, E. 1972. Santa Teresa de Jesús y la inquisición española: 54-194 Madrid: CSIC. Según Llamas no se conoce la identidad de este clérigo melancólico que ayudó a María del Corro en su denuncia.

${ }^{79}$ Santa Teresa, S. de (ed.). 1934-1935. Procesos de beatificación y canonización de Santa Teresa de Jesús: vol. III, XL Burgos. En esta fase importante de la vida de la santa, también jugó un gran papel el jesuita Enrique Enríquez, que igualmente fue su confesor en Sevilla y quien en los procesos de beatificación afirma que «Este testigo y el P. Rodrigo Álvarez, religioso de la Compañía de Sevilla, le tomaron cuenta de las cosas más importantes de toda su vida, para cierto fin importante y desengaño, mandándoselo a la dicha Teresa de Jesús su prelado, sin cuyo mandato no quería, por su mucha humildad, descubrir los dones grandes y misericordias que Dios obraba en su alma». Ibídem, vol. I, p. 15; Llamas Martínez, E. 1972: 108, n. 109.

${ }^{80}$ Muchos de estos casos de falsos visionarios insertó Rodrigo Álvarez en su manuscrito ya citado Suma de los solícitos engaños que el demonio hace en estos miserables tiempos. RAH, Ms. 12-26-7, D. 185, que tuvo que enseñar Enrique Enríquez ante su insistencia de que aprobara la espiritualidad de Teresa.

${ }^{81}$ Santa Teresa, S. de (ed.). 1934-1935: vol. I,15. La relación, de carácter inquisitorial, que la santa escribe con destino a Rodrigo Álvarez, se encuentra en la cuenta de conciencia $57^{\mathrm{a}}$ que se edita en
} 
No cabe duda, tal como piensa Llamas, que tras la confesión general Rodrigo Álvarez terminó por convencerse de la autenticidad de lo acontecido en la oración y en el espíritu de la santa. Finalmente esta, probablemente en mayo de 1576, fue absuelta de la denuncia y, tras ello, abandonó Sevilla el 4 de junio de ese mismo año para no regresar más. Pero ello no fue óbice para que a partir de ese momento, Rodrigo y Teresa establecieran una relación de consejo y complicidad espiritual que se vería objetivada en una relación epistolar, tal como nos demuestra el epistolario de la santa. Una relación que, sería continuada, por la descendencia espiritual de Rodrigo, Hernando de Mata y Bernardo de Toro que estrecharían sus lazos con el convento de San José de madres carmelitas descalzas fundado por la propia Teresa.

En esta relación de consejo espiritual, parece probable que Rodrigo Álvarez hubiese comunicado a la santa la famosa profecía de San Francisco de Paula. Teresa conoció la profecía del fundador de los mínimos, aunque parece que no hará una lectura en la línea de Gómez Camacho y sus descendientes, sino que más bien la aplicará a su propia orden.

No cabe duda de que Rodrigo Álvarez tuvo conocimiento a través de Gómez Camacho, que luego transmitirá a sus discípulos, en especial a Hernando de Mata, de la profecía del santo calabrés. Teresa también debió conocerla a juzgar por las revelaciones de que nos da cuenta en el libro de su vida: «Estando una vez en oración con mucho recogimiento y suavidad y quietud, parecíame estar rodeada de ángeles y muy cerca de Dios. Comencé a suplicar a Su Majestad por la Iglesia. Dióseme a entender el gran provecho que havía de hacer una Orden en los tiempos postreros, y con fortaleza que los de ella han de sustentar la fe». ${ }^{82}$ Aquí, como vemos, alude a esa orden última, supuestamente de los Crucíferos, que debía constituirse en el pilar sobre el que se sustentaría el reinado del Milenio. ${ }^{83}$

En otra ocasión, estando rezando ante el Santísimo Sacramento se le apareció un santo «cuya Orden ha estado algo decaída», que le dio a leer en un libro: «En los tiempos advenideros florecerá esta Orden; habrá muchos mártires». En otra ocasión, cuando Teresa se encontraba en el coro se le presentaron varios miembros de esa misma orden, que no dice cuál es, con espadas en las manos que ella interpretó como que habrían de defender la fe católica, sobre todo cuando en un arrebato de su espíritu: «parecióme estar en un gran campo, adonde se combatían muchos, y estos de esta Orden peleavan con gran hervor. Tenían los rostros hermosos y muy encendidos, y echavan muchos en el suelo vencidos,

\footnotetext{
Santa Teresa de Jesús. 1997. Obras completas: 617 Madrid: BAC, que lleva por título: Vicisitudes espirituales y memoria de confesores que tuvo en Sevilla, año 1576. Vid. Llamas, E. 1972: 112 y ss.

${ }^{82}$ Santa Teresa de Jesús. 1997: 226.

${ }^{83}$ Gracián de la Madre de Dios pensó que esta orden sería la de los dominicos, mientras que el primer biógrafo de la santa, el jesuita Ribera pensó que era la Compañía de Jesús. Ibídem: 226, n. 2.
} 
otros matavan. Parecíame esta batalla contra los herejes». Más adelante, los editores de las Obras de Teresa, intentan demostrar que esta adjudica las revelaciones a la propia orden reformada de los carmelitas descalzos.

Algunas muestras más de las virtudes espirituales de Rodrigo Álvarez, nos la ofrece Martín de Roa quien en su obra expone algunos casos que demuestran la capacidad de Álvarez para discernir espíritus y de encontrar detrás de muchos de ellos al demonio. ${ }^{84}$ Juan del Salto califica casi todos estos ejemplos como verdaderos, o bien porque el mismo Álvarez se los había contado y, tras su muerte, confirmado por haber aparecido escrito con su letra; o bien, porque fueron los mismos protagonistas los informantes del platero. Algunos de ellos volvían a tener protagonistas que Roa no explicita pero que Salto sí que lo hace. Afirma Roa que un siervo de Dios estando ejercitándose en algunas virtudes, «cosa que aborrece mucho el demonio», este trató de inquietarle, de asustarle con los gemidos de un niño, pero al ver que no se inmutaba el propio demonio exclamó: «maldito sea quien te lo enseñó», en clara alusión al maestro Álvarez. ${ }^{85}$ Juan del Salto nos informa del personaje: «le acaeció a su grande amigo y compañero Vasco Pereira». ${ }^{86}$

Asimismo, se narra cómo otros siervos de Dios, discípulos de Rodrigo, vieron un «gran número de demonios, que estando una vez el Padre hablando de Dios pasaban huyendo»; del mismo modo, cuando decía misa estaban cerca estos demonios «diciendo él misa entraban y salían en la iglesia con tan recios gritos y voces que ponían grandísimo espanto» ${ }^{87}$ Según Juan del Salto, el que vio los primeros demonios aludidos era «Antonio Camacho, hijo de Gómez Camacho, a quien el Padre Rodrigo Álvarez llamaba su padre espiritual». El que oyó los gritos de los demonios, cuando oficiaba misa el jesuita, fue Vasco Pereira; además, el propio Juan del Salto ayudaba a misa aquel día a Álvarez: «Acabada la missa le preguntó Perea (sic) al Padre cómo avía podido dezir missa, porque él avía oydo tales y tales cosas. El Padre sin darle de que él uviesse oydo nada respondió: no le dava ningún contento al demonio la misa que yo dezía». ${ }^{88}$

Álvarez también estuvo dotado del don de consejo, como buen confesor y hombre espiritual le llegaron muchas personas con problemas y la pretensión de ser aconsejadas. En varios casos se pondera ese don. Los narra Roa en su Historia. ${ }^{89} \mathrm{Al}$ parecer Rodrigo Álvarez aconsejaba sobre cualquier cosa; así, por ejemplo, a un anciano virtuoso recomendó que echase a su criada «o la pusiese en estado», el anciano lo olvidó por lo que más tarde, y tras el encuentro con otro

\footnotetext{
${ }^{84}$ Roa, M. de. 2005: 290-292 [201r.-203r.].

${ }^{85}$ Ibídem, p. 292 [203r.].

${ }^{86}$ ARSI. Baetica 25, Necrología I (1570-1648), fol. 36r.

${ }^{87}$ Roa, M. de. 2005: 292 [203r.].

${ }^{88}$ ARSI. Baetica 25, Necrología I (1570-1648), fol. 36v.

${ }^{89}$ Roa, M. de. 2005: 292-295 [203r.-205v.].
} 
«siervo de Dios», vio a muchos demonios que le decían: «ves allí el que recibió los consejos del Padre y no los guardó». ${ }^{90}$ Salto nos informa que esto «aconteció a Francisco de Castro çurujano». Roa narra que una persona respetable pidió a Rodrigo una misa por su padre enfermo. El jesuita aceptó pero dijo que sería una misa por su alma, al día siguiente se comprobó que fue verdad pues había fallecido: «esta persona era Doña Mencía de Rojas, prima del Padre Rodrigo Álvarez señora principal y rica en esta ciudad». ${ }^{91}$

Rodrigo Álvarez, El ElEGIDO DE DIOS PARA LIDERAR EN LA PARUSÍA LA REFORMA DE LA IGLESIA

El último capítulo de su Historia lo dedica Martín de Roa a narrar los favores especiales recibidos de Dios por el jesuita. Una persona, estando en oración ante el Santísimo Sacramento, llegó a ver a Rodrigo Álvarez que bajaba del cielo escoltado por dos eclesiásticos «que entonces confesaban con él», tras ellos venía un gran número de obispos, cardenales y sacerdotes «que entendió ser la jerarquía de la iglesia». Rodrigo traía en la mano derecha una antorcha encendida, la mitad inferior era vieja y la superior nueva que interpretaron como que «no es luz nueva sino aquella antigua de la primitiva iglesia; y es así que el espíritu y doctrina de este padre era muy de aquellos siglos, sólida y oliendo toda a Jesucristo». ${ }^{92}$

Tendencia evangélica y espíritu de Cristo, así vieron sus discípulos a Rodrigo Álvarez. Este mismo orante tuvo otra visión muy extraña. Observó «en espíritu al Padre Eterno que derramaba sobre la cabeza del buen Padre unas aguas cristalinas y tenía él en las manos un vaso delante del pecho donde ellas se recogían y donde llegaban muchos a beber de ellas». ${ }^{93}$ Juan del Salto nos revela ahora quién fue el orante visionario: «la persona que vio esto fue Juan Baptista Vázquez, escultor» ${ }^{94}$ Impresionan estas visiones del famoso escultor y cómo el carácter fuertemente iconográfico de las mismas se halla muy influido por su formación. Se entiende así las maravillosas creaciones de estos artistas, que mezclaron la vida real de su formación académica y la irreal de la visión y la trascendencia.

\footnotetext{
${ }^{90}$ Roa, M. de. 2005: 293 [203v].

${ }^{91}$ ARSI. Baetica 25, Necrología I (1570-1648), fol. 37r.

${ }^{92}$ Roa, M. de. 2005: 296 [206v.-207r.].

${ }^{93} \mathrm{Ibídem}$, [207r.]. Juan del Salto afirma que «de la qual visión quedó el susodicho con grande estima de la fecundidad de la doctrina del Padre Rodrigo Álvarez por ser la mesma del santo Evangelio y que tenemos de fee, y como la enseñaua con tan sobrenatural espíritu, así eran los efectos que en sus amigos pasauan sobrenaturales y muy conformes a lo enseñado». ARSI. Baetica 25, Necrología I (1570-1648), fol. $31 \mathrm{v}$.

${ }^{94}$ ARSI. Baetica 25, Necrología I (1570-1648), fol. 37r.
} 
Esta visión del célebre escultor y pintor tuvo una gran importancia. Molestó a Rodrigo Álvarez que Dios se manifestara de una forma tan concluyente a un simple oficial y no a una persona eclesiástica. Juan del Salto en su informe de Roma da una versión más ajustada que, además, va a provocar la ruptura del voto de silencio que Rodrigo tenía realizado:

...uno de los que comunicavan con el Padre estando en oración le vio en espíritu baxar del cielo con gran magestad como el mismo trage y ropa de la Compañía de Jesús, y a sus dos lados un sacerdote y un estudiante, sus espirituales hijos, con ciertos papeles o legajos en las manos, y estos estavan en muy alta disposición acerca del espíritu del Padre. El qual traía en la mano derecha una hacha encendida, la mitad vieja y la mitad hazía arriba nueva, y venianle siguiendo al Padre todas las hierarchias de la Santa Iglesia, grandíssima multitud de cardenales, y obispos, y prelados, y de todos los estados, y oyó una voz del cielo que le dixo: no es luz nueva, sino aquella luz antigua de la primitiva Iglesia, de la qual visión quedó el susodicho admirablemente illustrado en las cosas de la fe y de la Santa Iglesia. Fuéle a dar quenta de todo esto al Padre Rodrigo Álvarez, el quál admirado dixo: yo tengo cosa en mi espíritu que dize con eso? Qué es esto Señor (exclamó diziendo) y a officiales os manifestáis? Y aviendo passado estos y otros effectos dixo: cuarenta años a, que callo, ya no puedo más. Y fuesse al Padre Dotor Diego de Acosta, que a la sazón era Provincial de la Provincia del Andaluzía para que le soltasse los votos y juramentos que tenía hechos de no manifestarse, y luego dio quenta como a su Perlado, el qual le dio licencia para que se manifestasse a los que Dios se manifestava. ${ }^{95}$

Cuando Rodrigo Álvarez murió, el 14 de abril de $1587,{ }^{96}$ otro siervo de Dios vio en sueños el cielo abierto y muchos padres de la Compañía asomados mirando a la tierra, «oyó preguntar para quién se abría el cielo, y respondieron que para un Padre de ella que entonces había expirado». Juan del Salto afirma que el visionario fue el bordador «Pedro de Mesa, que oy bive». ${ }^{97}$

La interpretación de la visión de Juan Bautista Vázquez nos confirma el conocimiento que el grupo espiritual de Rodrigo Álvarez tenía de la profecía de San Francisco de Paula y cómo habían asumido ellos mismos, desde Marta de San Andrés y Gómez Camacho, el protagonismo que el descendiente de Simón de la Limena y los Crucíferos tenían en la misma. En esta visión triunfal de Juan Bautista Vázquez queda fijada la estructura del pensamiento religioso de este grupo de visionarios iluminados. Rodrigo Álvarez desciende del cielo con su hábito jesuítico escoltado por «un sacerdote y un estudiante, sus espirituales hijos», es decir, su descendencia mística: Hernando de Mata y Bernardo de Toro. Ambos llevan papeles y legajos en las manos, la autoridad de la letra escrita, como si fuesen doctores de la nueva Iglesia que es más antigua, por

${ }^{95}$ ARSI. Baetica 25, Necrología I (1570-1648), fol. 24r. En otra ocasión «uno de los que tratavan con el Padre vio una vez sobre su cabeça del dicho Padre una antorcha lucidíssima que alumbrava la iglesia de el Señor». Ibídem.

${ }^{96}$ ARSI. Cartas Triennales, fol. 20, atrasa tres días la fecha de la muerte: «El Padre Rodrigo Álvarez natural de Lebrija professo de 3 votos, morió a los 17 de abril de 1587».

${ }^{97}$ ARSI. Baetica 25, Necrología I (1570-1648), fol. 24r. 
más evangélica, que nunca; aunque, al mismo tiempo, es nueva por renovada. Tal vez entre algunos de esos legajos que lleva en las manos se encuentren las cartas proféticas de San Francisco de Paula, el manuscrito de Amadeo de Silva, el célebre Apocalipsis Nova, el Libro de los Estados de Gómez Camacho y el Soliloquium diuinum de Francisca de Vera. Rodrigo lleva un hacha encendida en la mano derecha, la mitad vieja y la otra nueva. Significa la renovación de la Iglesia que pretende. En ella él es el elegido, por eso viene acompañado de toda la hierarchia: cardenales, obispos, prelados, gentes de todos los estados que aclaman a los defensores de la fe nueva por antigua tal como dice la voz que salía del cielo: «no es luz nueva, sino aquella luz antigua de la primitiva Iglesia». ${ }^{98}$

La segunda visión de Juan Bautista Vázquez alude igualmente a esa idea de renovatio ecclesiae transmitida desde Francisco de Paula. Dios Padre aparece en ella en el momento preciso de esa renovatio, justo cuando renueva el bautismo de Rodrigo Álvarez que se presenta como un nuevo Jesucristo, en lo que parece la creación de una nueva Iglesia, la vieja, la primigenia, la del evangelio, ahora renovada, que es transmitida en absoluta legitimidad a sus discípulos que se acercan a tomar, de Dios por medio de Álvarez, el agua renovadora. Eso sería, sin duda, lo que fue a buscar a Sevilla el célebre lebrijano Rodrigo de Valer, de la misma escuela, cuya idea entroncará perfectamente con los «intelectuales» de la reforma luterana sevillana objetivada en Egidio. ${ }^{99}$

Por tanto, vemos a un grupo de seguidores, pertenecientes a una escuela espiritual, que siguen a su maestro y se ejercitan con él en la oración mental e, incluso, en la práctica profética y adivinatoria. Acuden a la Casa Profesa de la Compañía de Jesús en la que el maestro, Rodrigo Álvarez, es confesor, también en ocasiones visitan enfermos. ${ }^{100}$ Rodrigo les realiza y modera pláticas doctrinales dentro de la más pura ortodoxia pero lo atrayente de su personalidad, a pesar de su desagradable aspecto, hacen que esas pláticas produzcan en sus seguidores efectos especiales:

como siempre que hablava el Padre Rodrigo Álvarez a sus allegados de Dios y repetía la dotrina christiana el Padre nuestro, el Avemaría, el Credo, los mandamientos, eran tales los effectos que causaba en el espíritu, que parecía aber oído la cosa más nueba del mundo, y conferían unos con otros diziendo: Válame Dios ermanos, esta dotrina y

${ }^{98}$ González Polvillo, A. 2009/2010: 47-72.

${ }^{99}$ En la línea del destino de los Crucíferos de Paula, Farfán escribía en su informe que «en la fin del mundo y en tiempo del Anticristo los que fueren vivos de esta Congregación han de morir mártires por la confesión de la fe y del evangelio de Nuestro Señor Jesucristo; y que los que ya fueren muertos de la dicha Congregación, en aquel tiempo del Anticristo han de resucitar para pelear contra el dicho Anticristo, de los cuales dicen que se entienden literalmente aquellas palabras de San Pablo, 1 ad Thesalonicenses 4,15: et mortui qui in Christo sunt resurgent primi». Vid. Huerga, A. 1988: 491.

${ }^{100}$ ARSI. Cartas Triennales 1583, aparece Rodrigo Álvarez como que «fue Maestro de novicios y ahora confiesa los de casa». En la de 1585 aparece como «Confesor».

Hispania Sacra, LXIV

129, enero-junio 2012, 141-186, ISSN: 0018-215-X, doi: 10.3989/hs.2012.005 
estas oraciones no es lo mesmo que tenemos de fe?, y lo que desde nuestra niñez avemos aprendido y sabemos? Pues qué novedad es esta? Qué nueva vida nos dan estas palabras? Porque bastava oylle dezir como al descuido: Carne que Dios juntó a sí, para engendrar en el alma un grave dolor de aver manchado con el peccado carne que Dios juntó a sí. Y bastava que él dixesse: Dios colgado del pecho de una doncella, para imprimir en el espíritu estima y agradecimiento de los beneficios de Dios. ${ }^{101}$

En buena medida, se puede extraer de su lectura que gran parte del informe de Juan del Salto sobre los hechos sobrenaturales ocurridos a Rodrigo Álvarez, o a sus discípulos, se debe a la propia biografía del orífice, a sus propias experiencias espirituales relacionadas con el maestro. Si atendemos al informe sobre la Congregación de la Granada que realizó el maculista, por dominico, Domingo Farfán en 1626, Juan del Salto fue uno de los seis del particular espíritu, es decir, estaba en posesión del famoso secreto de los particulares que se iba transmitiendo por generaciones. ${ }^{102}$ De la lectura del informe de Salto es posible deducir el momento, y los encontrados sentimientos, de la transmisión de ese secreto a su propia persona por parte de Rodrigo Álvarez. Salto afirma que:

un día cierta persona de los íntimos amigos del Padre Rodrigo Álvarez le fue a hablar en particular y a las primeras razones, se puso el Padre como en rapto, su rostro blanco, i diferente, y la persona, toda como absorta. Y díxole el Padre al susodicho, guardarme a secreto? Y tomole juramento de tener secreto lo que a él le dixesse (y assí guarda su juramento hasta oy) y el Padre le dio quenta de un negocio grave que Dios le avía dicho, y revelado y estuvo hablando con aquella sobre natural disposición (a lo que le parece a esta persona) como media ora. Y al cabo della quedó como quien descansa, o buelve en otra disposición, quedando el Padre en su natural y dixo: no pensé hablar lo que aquí e hablado, y no me pesa de averle dicho, vaya y dé gracias a Dios aý en la Iglesia, y no se descuide en darme crédito en las cosas que le aconsejo, ni en hazer lo que le digo que haga porque le vendrá un castigo, y diziendo y haziendo, como quien ve presente el castigo con el don profético, se encogió de ombros y hizo una demonstración del trabaxo, como que el Padre lo sintiera en sí, que no se puede sinificar como hizo, y mostró aquel sentimiento y con esto el contenido se fue. ${ }^{103}$

Salto no termina aquí su relato. Al parecer, a los pocos días comenzó a dudar sobre la veracidad del secreto desvelado, incluso llegaba a tener envidia respecto del trato del maestro con otros discípulos, a pesar de que el secreto «no se avía dicho a todos». Esta duda, atribuida por Salto a los demonios, le costó una enfermedad pues un día cuando se encontraba en la Casa Profesa cayó al suelo «mudado el rostro como difunto». Creyó que moriría. Estuvo enfermo en

\footnotetext{
${ }^{101}$ ARSI. Baetica 25, Necrología I (1570-1648), fol. 20r.-20v.

${ }^{102}$ «hay en esta Congregación un secreto singularísimo reservado en el pecho de las cabezas de ella, que no se comunica sino solo a los que llaman ellos del particular espíritu, los cuales hacen juramento de no manifestarlo a nadie, si no fuese al Sumo Pontífice, al Rey, al Obispo y al Santo Oficio». Huerga, A. 1988: 221.

${ }^{103}$ ARSI. Baetica 25, Necrología I (1570-1648), fol. 20v.
} 
la cama prácticamente desahuciado. Pensó que era un castigo por haber dudado de la veracidad del secreto y así se lo hizo saber a Rodrigo: «Padre V.R. me dixo que me avía de venir un gran castigo, vea aquí V.R. el castigo cumplido, qué remedio?» El jesuita le contestó que ya todo había pasado y «que le diesse crédito».

Pero Juan del Salto aún no se lo daba. Pretendió ordenar la celebración de una misa cada día para conseguirlo, pues «no avía acabado el dicho ombre de darle crédito al Padre de todo punto, y todas las vezes que se dexava tentar contra él, y no le dava crédito a lo que le avía dicho, se le aumentava la tribulación, pena y trabaxo interior, y quando acudía al Padre por remedio, respeto de la fe, o confiança que llevava, assí hallava al Padre o alegre, o severo, y grave, que temblava delante dél». Fruto de este miedo llegó a ver por dos veces el rostro de Rodrigo transformado en el de Jesucristo «severo y ayrado como lo tendrá el día del juyzio, porque así se lo dieron a entender en su espíritu al dicho afligido, el qual rostro era terrible cosa mirarle». Las dos veces que esto ocurrió fue porque «iva muy tentado contra el Padre y falto de fe y confiança de Dios».

Parece obvio que el sufrimiento de Salto solo podía terminar si creía de una vez en Rodrigo Álvarez, pero lo revelado debió ser muy difícil de creer para que un hombre crédulo como nuestro orífice tuviese enormes escrúpulos en aceptarlo. Una noche cuando Juan del Salto se hallaba acostado en su cama una luz le decía: «si tuviesses fe de lo que te a dicho el Padre en ese punto estarías libre de ese trabaxo». Lo contó a Álvarez, quien exclamó: «¿Tan mal ombre era yo, que avía de levantar a Dios testimonio?».

Juan del Salto siguió persistente en la duda y Rodrigo Álvarez más porfiado en lo revelado: «lo que una vez digo, para siempre lo digo», le contestó en una ocasión en su celda de la Casa Profesa. El platero se tranquilizó de momento. Unos días más tarde, cuando Álvarez oficiaba una misa en la que se encontraba Salto, y al tiempo que el sacerdote tenía en sus manos el Santísimo Sacramento, y el platero aún persistía en la duda, este volvió a repetir «lo que una vez digo para siempre lo digo». Para Juan del Salto aquellas palabras fueron dichas por el mismo Dios que Alvarez tenía en ese momento en su mano: «sintió su coraçón corroborado, y de tímido y desconfiado, y flaco quedó confiado i fuerte, i con un sentir altamente de la divina providencia de Dios». Sin embargo, cuando murió Rodrigo Álvarez otra vez volvieron a Salto las dudas: «como se vido sin el Padre a quien acudía, y se vio tentado, sobreveníale la tentación y desconfiança acerca del Padre». En esta ocasión también se vio socorrido por el jesuita pues «le vio en espíritu asomar por el cielo, y le dixo: Queréis gloria, pues ama los medios, -que eran las palabras con que le ayudava biviendo en esta vida- y con esto se sintió con nueva vida y brío, y cobró fuerças, para passar sus tribulaciones». ${ }^{104}$ $22 \mathrm{r}$.

${ }^{104}$ El relato de la transmisión del secreto en ARSI. Baetica 25, Necrología I (1570-1648), fol. 20v.-

Hispania Sacra, LXIV

129, enero-junio 2012, 141-186, ISSN: 0018-215-X, doi: 10.3989/hs.2012.005 


\section{La InMACUlada CONCEPCión COMO ANUNCIO DE LA PARUSía}

Solo quedaba saber cuándo se produciría la Parusía, esa segunda venida triunfal de Cristo con la que daría comienzo el Milenio. Ya vimos cómo Joaquin de Fiore la había fijado para 1260 y cómo el propio San Francisco de Paula, doscientos años más tarde, en 1460, escribía a Simón de la Limena sobre la inminencia de la misma. Casi un siglo después, Gómez Camacho había advertido, como veíamos más arriba que se recogía en el memorial que Bernardo de Toro envió en 1615 a don Bernardo de Sandoval y Rojas, de la seguridad de la concepción inmaculada de la Virgen María y cómo profetizaba sobre lo imperioso de escribir esta afirmación «porque los años adelante auía de ser necessario este testimonio en la Santa Iglesia». Ya en el siglo XVII, y tras la persecución que, a instancias de miembros de la orden de Santo Domingo, sufrió por parte del Santo Oficio la Congregación de la Granada, en el informe que el 4 de mayo de 1626 el dominico Domingo Farfán realizaba para la Suprema, se informaba de la profecía básica de estos congregados: «tienen los de esta Congregación por particular y cierta observancia y como profecía que, en definiéndose por de fe el punto de la Concepción de Nuestra Señora, habían de reformar la Iglesia los congregados de la dicha Congregación». ${ }^{105}$

Se profetizaba que el momento de la definición del dogma inmaculista era el elegido para la Parusía así como para el desempeño de la misión de lucha y de renovatio ecclesiae de la Congregación de la Granada, de ahí la intensa labor realizada tanto en Sevilla, como en Madrid ante Felipe III y en Roma ante Paulo V, Gregorio XV y Urbano VIII por el cabeza de la Congregación, Bernardo de Toro, para conseguir la definición. ${ }^{106}$ La Virgen Inmaculada aparecía, para nuestros congregados, como una nueva Eva que anunciaba así la nueva Iglesia, la Iglesia evangélica, la Iglesia del Milenio, reformada por ellos mismos. La propia profecía tuvo su concreción iconográfica en la Inmaculada cuando la figura de Rodrigo Álvarez que aparecía en la visión de Juan Bautista Vázquez,

${ }^{105}$ Entre otras creencias de la Congregación de la Granada, descubiertas por Farfán, y que coinciden con la profecía de San Francisco de Paula, se encuentran la de que, llegado el fin del mundo, en tiempos del Anticristo, aquellos que llegasen vivos de la Congregación de la Granada habrían de morir mártires por la confesión de la fe del Evangelio de Cristo; por otro lado, los ya fallecidos en ese momento resucitarían para luchar contra el Anticristo. Domingo Farfán, Informe calificador sobre la Congregación de la Granada. A.H.N. Inquisición, leg. 2963/1.

${ }^{106}$ Para seguir buena parte de estos hechos Vid. Serrano Ortega, M. 1893. Glorias sevillanas. Noticia histórica de la devoción y culto que la muy noble y muy leal ciudad de Sevilla ha profesado a la Inmaculada Concepción de la Virgen María desde los tiempos de la Antigüedad hasta la presente época. Sevilla: E. Rasco. Hazañas y La Rúa, J. 1918. Vázquez de Leca. 1573-1649. Sevilla: Sobrinos de Izquierdo. Ollero Pina, J. A. 2003. ««Sine Labe Concepta»: conflictos eclesiásticos e ideológicos en la Sevilla de principios del siglo XVII», en C. A. González Sánchez; E. Vila Vilar (comp.), Grafías del imaginario. Representaciones culturales en España y América (siglos XVI-XVIII): 301-335. México: FCE. 
que denominamos Triunfo de Rodrigo Álvarez, es permutada, casi cincuenta años más tarde de haber tenido lugar esa visión, por la imagen simbólica de la nueva Iglesia, o sea, la Inmaculada, en el lienzo diseñado por Bernardo de Toro, Triunfo de la Inmaculada Concepción, que se realizó en Roma en 1633. ${ }^{107}$

A modo de conclusión y a la vista de esta especie de árbol genealógico místico, y visionario, hemos podido establecer la personalidad religiosa, inserta en una línea genealógico-espiritual muy determinada, del confesor y calificador del espíritu de Teresa de Ávila, Rodrigo Álvarez. Se trata de una espiritualidad evangélica, profética, milenarista, apocalíptica, escatológica, mesiánica y visionaria cuya combinación anuncia las singulares veleidades alumbradistas del barroco sevillano. Hemos establecido su genealogía con las raíces paulino-mínimas jerezanas y lebrijanas así como sus entronques sevillanos, que nos permite mejorar nuestro conocimiento sobre la espiritualidad visionaria y profética pero también evangélico-paulina y de vuelta a la Iglesia primitiva de aquel famoso grupo luterano de Sevilla en la que se produjo la fusión de esta espiritualidad jerezano-lebrijana con la intelectualidad, entre otros, de algunos miembros del cabildo catedral. Asimismo arrojamos nueva luz sobre la herencia de ese grupo objetivada en aquella Congregación de la Granada, perseguida por la Inquisición en las primeras décadas del Seiscientos, que tanto interesara al recordado don Antonio Domínguez Ortiz y, en buena medida, informamos sobre las razones que fundamentan la especialísima religiosidad barroca de la sociedad sevillana del siglo XVII.

\section{BiBLIOGRAFÍA}

Álvarez Santaló, L. C. 2003. «La aparición visionario conventual: anatomía sugerente del «paisaje con figuras» revelado (siglos XII-XVII)», en D. González Cruz (ed.), Ritos y ceremonias en el Mundo hispánico durante la Edad Moderna: 43-90. Huelva: Universidad de Huelva.

Álvarez Santaló, L. C. 2005. «Palabra de Dios, pluma de claustro. El discurso literal de la divinidad y sus adyacentes en la revelación visionaria barroca», en M. Vitse (ed.), Homenaje a Henri Guerreiro: 169-227 Madrid Iberoamericana-Vervuert.

Boeglin, M. 2007. «Valer, Camacho y los «cautivos de la Inquisición». Sevilla 15401541». Cuadernos de Historia Moderna, 32: 114-134.

Calero Palacios, M. C. 1999. La abadía del Sacromonte de Granada: catálogo de manuscritos. Granada

${ }^{107}$ Se trata del lienzo Triunfo de la Inmaculada Concepción que en 1633 Bernardo de Toro encargara en Roma a Luigi Primo Gentile con destino al hospital de Santiago de los Españoles, situado entonces en la Piazza Navona de la ciudad eterna, hoy conservado en la Iglesia de Montserrat y Santiago de la misma ciudad, en el que se muestra a la Virgen Inmaculada acompañada de toda esa hierarchia a la que aludía la visión del famoso escultor Juan Bautista Vázquez. Vid. González Polvillo, A. 2009/2010: 54-55.

Hispania Sacra, LXIV

129, enero-junio 2012, 141-186, ISSN: 0018-215-X, doi: 10.3989/hs.2012.005 
Campese Gallego, F. 2008. «Gómez Camacho: Un profeta paradójico en el Siglo de Oro», en Investigaciones históricas, 28: 11-28.

Castrillo Benito, N. 1991. El «Reginaldo Montano»: primer libro polémico contra la Inquisición Española. Madrid: CSIC.

Cohn, N. 1989. En pos del Milenio. Revolucionarios milenaristas anarquistas místicos de la Edad Media. Madrid: Alianza editorial.

Domínguez Ortiz, A. 1980. «La Congregación de la Granada y la Inquisición de Sevilla. Un episodio de la lucha contra los 'alumbrados', en La Inquisición española. Nueva visión, nuevos horizontes. Madrid.

Domínguez Ortiz, A. 1983. Sociedad y mentalidad en la Sevilla del Antiguo Régimen. Sevilla.

Fernández López, J. 2002. Programas iconográficos de la pintura barroca sevillana del siglo XVII: 43-53 Sevilla: Universidad de Sevilla.

Fraga Iribarne, M. L. 1993. Conventos femeninos desaparecidos. Arquitectura religiosa perdida durante el siglo XIX en Sevilla. Sevilla.

Gil, J. 2005. «Nuevos documentos sobre Rodrigo de Valer», en P. M. Piñero (coord.) Dejar hablar a los textos: Homenaje a Francisco Márquez. Villanueva. 739-774 Sevilla: Secretariado de Publicaciones de la Universidad.

González Polvillo, A. 2009/2010. «La Congregación de la Granada, el inmaculismo sevillano y los retratos realizados por Francisco Pacheco de tres de sus principales protagonistas: Miguel Cid, Bernardo de Toro y Mateo Vázquez de Leca». Atrio. Revista de Historia del Arte. 15-16 47-72.

González Polvillo, A. 2011. «Inquisidores, dominicos y alumbrados de la Congregación de la Granada en la génesis del inmaculismo sevillano del siglo XVII». Anuario de Historia de la Iglesia Andaluza: 117-142.

Hazañas y La Rúa, J. 1918. Vázquez de Leca. 1573-1649. Sevilla: Sobrinos de Izquierdo.

Huerga, A. 1988. Historia de los alumbrados (1570-1630). IV Los alumbrados de Sevilla (1605-1630). Madrid: FUE.

Huerga, A. 1992. Los dominicos en Andalucía. Sevilla.

Jesús María, P. de. 1663. Vida, virtudes y dones soberanos del venerable y apostólico padre Hernando de Mata, con elogios de svs principales dicipvlos. Por Fr. Pedro de Iesv María, Monge de la Congregación Reformada, del Orden de san Basilio Magno, del Yermo del Tardón. Dedicalo al Mysterio de la Inmaculada Concepción de María Santíssima señora Nuestra. Málaga: Mateo López Hidalgo.

Llamas Martínez, E. 1972. Santa Teresa de Jesús y la inquisición española. Madrid: CSIC.

Llorca, B. 1980. La Inquisición española y los alumbrados: (1509-1667): según las actas originales de Madrid y de otros archivos. Salamanca.

López Muñoz, T. 2011. La Reforma en la Sevilla del siglo XVI: 2 vols. Sevilla: MAD.

Martínez Millán, J. 1998. «Transformación y crisis de la Compañía de Jesús (15781594), I religiosi o corte. Teologia, Politica e Diplomazia in Antico Regime. Atti del seminario di studi Georgetown University a Villa «Le Balze». Fiesole, 20 ottobre 1995: 101-129. Roma: Bulzoni.

Menéndez Pelayo, M. 1987. Historia de los heterodoxos españoles. Madrid: BAC. 
Montoya, L. de. 1619. Crónica General de la Orden de los Mínimos de San Francisco de Paula su fundador: donde se trata de su vida y milagros, origen de la Religión, erection de Prouincias y varones insignes della. Madrid: Bernardino de Guzmán.

Ollero Pina, J. A. 2003. «Sine Labe Concepta»: conflictos eclesiásticos e ideológicos en la Sevilla de principios del siglo XVII», en C. A. González Sánchez; E. Vila Villar (comp.), Grafías del imaginario. Representaciones culturales en España y América (siglos XVI-XVIII): 301-335. México: FCE.

Pacheco, F. 1985. Libro de descripción de verdaderos retratos e ilustres y memorables varones. Edición de P. M. Piñero y R. Reyes. Sevilla.

Palomero Páramo, J. M. 1986. «Juan Bautista Vázquez el Viejo y el retablo de la Virgen de la Piña, de Lebrija», Archivo Hispalense, 210.

Roa, M. de. 2005. Historia de la Provincia de Andalucía de la Compañía de Jesús (1553-1662). Edición de A. Martín; I. Carrasco. Écija.

Sánchez Lora, J. L. 1998. Mujeres, conventos y formas de la religiosidad barroca. Madrid: FUE.

Santa Teresa, S. de (ed.). 1934-1935. Procesos de beatificación y canonización de Santa Teresa de Jesús. Burgos. 